\title{
Tropical Atlantic climate and ecosystem regime shifts during the Paleocene-Eocene Thermal Maximum
}

\author{
Joost Frieling ${ }^{1}$, Gert-Jan Reichart ${ }^{2,3}$, Jack J. Middelburg ${ }^{2}$, Ursula Röhl ${ }^{4}$, Thomas Westerhold ${ }^{4}$, Steven M. Bohaty ${ }^{5}$, \\ and Appy Sluijs ${ }^{1}$ \\ ${ }^{1}$ Marine Palynology and Paleoceanography, Laboratory of Palaeobotany and Palynology, Department of Earth \\ Sciences, Faculty of Geosciences, Utrecht University, Heidelberglaan 2, 3584CS Utrecht, the Netherlands \\ ${ }^{2}$ Department of Earth Sciences, Faculty of Geosciences, Utrecht University, Princetonplein 9, \\ 3584CC Utrecht, the Netherlands \\ ${ }^{3}$ NIOZ Royal Netherlands Institute for Sea Research, 1790AB Den Burg, Texel, the Netherlands \\ ${ }^{4}$ MARUM - Center for Marine Environmental Sciences, University of Bremen, Leobener Straße 8, 28359, Bremen, Germany \\ ${ }^{5}$ Ocean and Earth Science, National Oceanography Centre Southampton, University of Southampton, Waterfront Campus \\ European Way Southampton, SO14 3ZH, UK
}

Correspondence: Joost Frieling (j.frieling1@uu.nl)

Received: 2 June 2017 - Discussion started: 20 June 2017

Revised: 25 October 2017 - Accepted: 13 November 2017 - Published: 15 January 2018

\begin{abstract}
The Paleocene-Eocene Thermal Maximum (PETM, 56 Ma) was a phase of rapid global warming associated with massive carbon input into the ocean-atmosphere system from a ${ }^{13} \mathrm{C}$-depleted reservoir. Many midlatitude and high-latitude sections have been studied and document changes in salinity, hydrology and sedimentation, deoxygenation, biotic overturning, and migrations, but detailed records from tropical regions are lacking. Here, we study the PETM at Ocean Drilling Program (ODP) Site 959 in the equatorial Atlantic using a range of organic and inorganic proxies and couple these with dinoflagellate cyst (dinocyst) assemblage analysis. The PETM at Site 959 was previously found to be marked by a $\sim 3.8 \%$ negative carbon isotope excursion (CIE) and $\mathrm{a} \sim 4^{\circ} \mathrm{C}$ surface ocean warming from the uppermost Paleocene to peak PETM, of which $\sim 1^{\circ} \mathrm{C}$ occurs before the onset of the CIE. We record upper Paleocene dinocyst assemblages that are similar to PETM assemblages as found in extratropical regions, confirming poleward migrations of ecosystems during the PETM. The early stages of the PETM are marked by a typical acme of the tropical genus Apectodinium, which reaches abundances of up to $95 \%$. Subsequently, dinocyst abundances diminish greatly, as do carbonate and pyritized silicate microfossils. The combined paleoenvironmental information from Site 959 and a close-by shelf site in Nigeria implies the general absence
\end{abstract}

of eukaryotic surface-dwelling microplankton during peak PETM warmth in the eastern equatorial Atlantic, most likely caused by heat stress. We hypothesize, based on a literature survey, that heat stress might have reduced calcification in more tropical regions, potentially contributing to reduced deep sea carbonate accumulation rates, and, by buffering acidification, also to biological carbonate compensation of the injected carbon during the PETM. Crucially, abundant organic benthic foraminiferal linings imply sustained export production, likely driven by prokaryotes. In sharp contrast, the recovery of the CIE yields rapid ( $\ll 10 \mathrm{kyr})$ fluctuations in the abundance of several dinocyst groups, suggesting extreme ecosystem and environmental variability.

\section{Introduction}

Long-term gradual warming during the late Paleocene and early Eocene $(\sim 59-53 \mathrm{Ma})$ is recorded in the deep ocean (Zachos et al., 2008; Littler et al., 2014), as well as Southern Hemisphere (Bijl et al., 2009; Hollis et al., 2012) and Northern Hemisphere (Frieling et al., 2014) midlatitude and high-latitude surface oceans and the equatorial Atlantic (Cramwinckel et al., 2018). Superimposed, the PaleoceneEocene Thermal Maximum (PETM) represents a transient 
period of rapid global warming, associated with the massive input of strongly ${ }^{13} \mathrm{C}$-depleted carbon into the oceanatmosphere system (Dickens et al., 1995; Zeebe et al., 2009). This results in a $\sim 2.5-8 \%$ o negative carbon isotope excursion (CIE) in carbon-bearing substrates deposited during the PETM (McInerney and Wing, 2011; Sluijs and Dickens, 2012). The CIE has a distinct shape: a rapid "onset" (1-5 kyr; Kirtland Turner and Ridgwell, 2016; Zeebe et al., 2016) followed by a prolonged (50-100 kyr) period, the "body", of stable low ${ }^{13} \mathrm{C}$ values and a recovery that lasts $42-82 \mathrm{kyr}$ (Röhl et al., 2007; Abdul Aziz et al., 2008; Murphy et al., 2010; Westerhold et al., 2017) to values that remain slightly ${ }^{13} \mathrm{C}$-depleted $(0.5-1 \%$ ) relative to the latest Paleocene. This pattern is best explained by massive ( $\gg 1500 \mathrm{Gt})$ carbon input from at least one but likely multiple reservoirs in the shape of $\mathrm{CO}_{2}$ and/or $\mathrm{CH}_{4}$; (Dickens et al., 1995; Panchuk et al., 2008; Zeebe et al., 2009; Dickens, 2011; Zeebe, 2013; Frieling et al., 2016; Luo et al., 2016).

The integrated changes in climate and the carbon cycle lead to global average surface warming during the PETM of the order of $\sim 4-5^{\circ} \mathrm{C}$ (Dunkley Jones et al., 2013; Frieling et al., 2017), although this warming was not equally distributed across the globe. Regions of enhanced warming are recognized in both the northern midlatitudes and southern midlatitudes and high latitudes, which shows that the mechanism underlying extratropical amplification was not fully saturated even in these strong greenhouse climates (Frieling et al., 2017). The warming during the PETM is associated with sea level rise (Sluijs et al., 2008b), local photic zone euxinia (Sluijs et al., 2006, 2014; Frieling et al., 2014, 2017), global expansion of anoxic waters (Dickson et al., 2012), and an accelerated hydrological cycle (Pagani et al., 2006; Schmitz and Pujalte, 2007; Sluijs and Brinkhuis, 2009; Handley et al., 2012; Carmichael et al., 2017).

The magnitude of warming during the PETM and environmental and ecological effects have been extensively documented at midlatitude and high-latitude sections (see review in Sluijs et al., 2014). Although micropaleontological studies indicate assemblage shifts and environmental perturbation in several tropical open ocean regions (e.g., Ocean Drilling Program (ODP) Site 865; Kelly et al., 1996, ODP Site 1001; Bralower et al., 1997), the underlying mechanisms remain unclear because causal relations with physicochemical parameters are difficult to establish. Evidence from Tanzania, Nigeria, and ODP Site 865 indicates that tropical surface oceans warmed by $\sim 3{ }^{\circ} \mathrm{C}$ (Frieling et al., 2017). In the modern ocean, a relatively modest $\left(0.5-1{ }^{\circ} \mathrm{C}\right)$ warming already negatively affects biodiversity in tropical regions (Pandolfi et al., 2011). In the Anthropocene, migrations to higher latitudes are noted in a multitude of biota (Doney et al., 2012), similar to the PETM (Kelly et al., 1996; Crouch et al., 2001; Wing et al., 2005; Sluijs et al., 2007b), notably in the (sub)tropical dinoflagellate cyst (dinocyst) Apectodinium.

Recently, a massive decrease in abundance and diversity of dinocysts was found during the PETM in Nigeria, which was attributed to heat stress (Frieling et al., 2017). The impact and geographical extent of this heat-stress-driven biodiversity drop, however, remain unknown, although similar heat-stress effects on marine biota may have been widespread in tropical regions (Aze et al., 2014; Yamaguchi and Norris, 2015). Although other stressors like stratification, salinity fluctuations, and acidification may play a role, it should be noted that dinoflagellates typically thrive under such conditions, including high $\mathrm{CO}_{2}$ (Hoins et al., 2015). Here, we analyze the PETM from ODP Site 959 in the equatorial Atlantic (Fig. 1) as recently described using carbon isotope stratigraphy, biostratigraphy, and $\mathrm{TEX}_{86}$ paleothermometry (Frieling et al., 2018a). Site 959 is located near the top of the Côte d'Ivoire-Ghana Transform Margin (CIGTM), a submarine high $\sim 150 \mathrm{~km}$ offshore Côte d'Ivoire (Shipboard Scientific Party, 1996). Upper Paleocene and lower Eocene sediments were deposited at a paleolatitude of $3-7^{\circ} \mathrm{S}$ (Seton et al., 2012; van Hinsbergen et al., 2015) and are typically composed of roughly equal amounts of carbonate, biogenic silicate, and siliciclastics (Shipboard Scientific Party, 1996; Wagner, 2002) with some $(0.1-1 \%)$ organic matter. We measure bulk magnetic susceptibility and apply inorganic proxies, including X-ray fluorescence core scanning and bulk sediment chemistry, and combine these with dinocyst assemblages and previously published $\mathrm{TEX}_{86}$ branched and isoprenoid tetraether (BIT) index data (Frieling et al., 2018a) to reconstruct environments across the PETM.

\section{Material}

The ODP recovered a relatively complete Cretaceous and Cenozoic sediment sequence from Hole 959D, located on the CIGTM, in $1995\left(3^{\circ} 37.656^{\prime} \mathrm{N}, 2^{\circ} 44.149^{\prime} \mathrm{W}\right.$; Fig. 1). From the Early Cretaceous onwards, the submarine high has been subsiding, reaching bathyal depths around the CretaceousPaleogene boundary (Oboh-Ikuenobe et al., 1997); the present-day water depth is $\sim 2000 \mathrm{~m}$ (Shipboard Scientific Party, 1996). Calcareous nannofossil biostratigraphy indicates the presence of the upper Paleocene CP8a-CP8b zone boundary in the interval from core section $41 \mathrm{R}-6$ to core section 42R-2 (Shafik et al., 1998). The PETM was identified in core section 42R-1 and spans the interval 804.1$802.6 \mathrm{~m}$ below sea floor (m b.s.f.) based on the identification of a $\sim 4 \%$ negative $\mathrm{CIE}$ and $\sim 4{ }^{\circ} \mathrm{C}$ warming (Frieling et al., 2018a; Fig. 2). Unfortunately, the top of the CIE lies within the $\sim 1 \mathrm{~m}$ gap between Cores $41 \mathrm{R}$ and $42 \mathrm{R}$. Notable lithological changes occur in the interval from 804.1 to $\sim 803.8 \mathrm{~m}$ b.s.f., where dominantly carbonate and siliciclastic sedimentation is, for a substantial part, replaced by diagenetically altered biogenic silicates (porcellanite; Shipboard Scientific Party, 1996; Wagner, 2002). The sediments above section 41R-6 are recognized by more frequent occurrences of porcellanite (Shipboard Scientific Party, 1996; Wagner, 2002). Sediments below core section $42 \mathrm{R}-1$ show apparently 


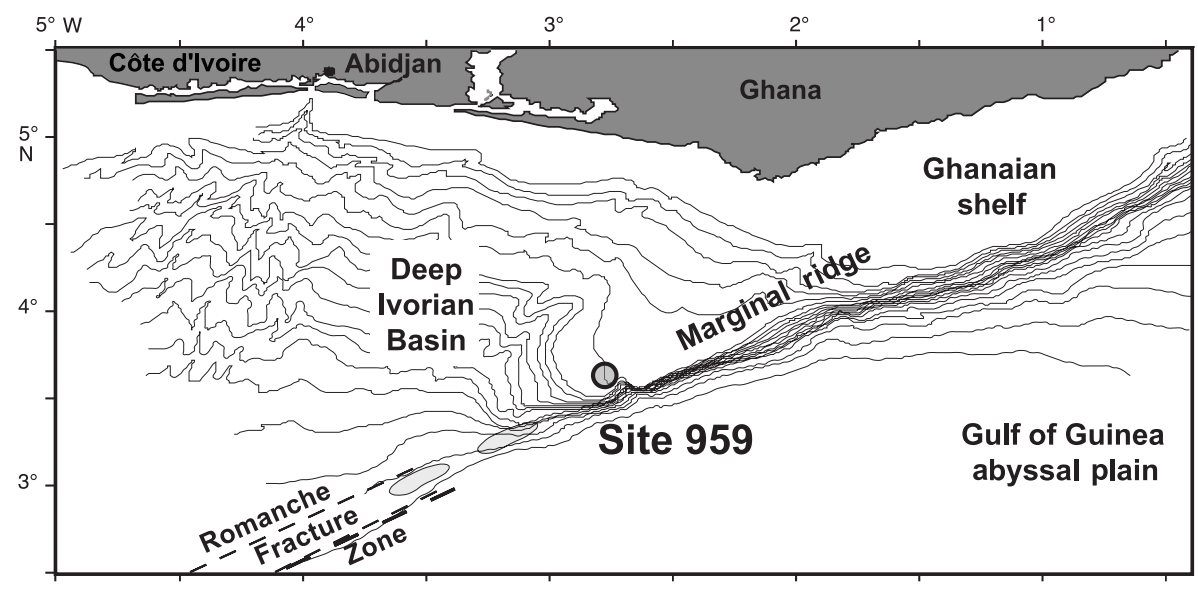

Figure 1. Map of eastern tropical Atlantic and location of ODP Site 959.

cyclic dark-light alterations, representing variable amounts of clay, carbonate, and biogenic silica (Shipboard Scientific Party, 1996; Wagner, 2002). The position of the site, near the top of a submarine high, explains the relatively sparse siliciclastic supply to the core location. We continuously sampled sections 41R-6, 41R-CC, 42R-1, and 42R-2 at the Bremen Core Repository (BCR) of the International Ocean Discovery Program (IODP), representing the interval from 800.5 to $805.58 \mathrm{~m}$ b.s.f. at a resolution of $1-3 \mathrm{~cm}$ (see Frieling et al., 2018a).

Frieling et al. (2018a) recorded a $\sim 4 \%$ negative CIE in the interval from 804.1 to $803.8 \mathrm{~m}$ b.s.f. (Fig. 2). Notably, this interval is marked by organic-lean biogenic silica and siliciclastics, which are likely derived from an allochthonous, potentially turbiditic, deposit, as reflected by anomalous $\mathrm{Ti} / \mathrm{Al}$ ratios (Frieling et al., 2018a; see also Fig. 3h in this paper). Carbon isotope stratigraphy of total organic carbon $\left(\delta^{13} \mathrm{C}_{\mathrm{TOC}}\right)$ indicates the presence of a $2 \%$ negative step at the base of the porcellanite ( $804.1 \mathrm{~m}$ b.s.f.), interpreted as the onset of the CIE, and stable low $(\sim-30 \%$ ) values from 803.8 to $803 \mathrm{~m}$ b.s.f., interpreted as the body phase of the CIE (Frieling et al., 2018a, Fig. 2a). The gradual decrease from $\sim-27 \%$ at $804.09 \mathrm{~m}$ b.s.f. to $-30 \%$ at $803.8 \mathrm{~m}$ b.s.f. is interpreted as a mixing line between organic matter produced during the Paleocene and the PETM (Frieling et al., 2018a). From 803 to $802.6 \mathrm{~m}$ b.s.f. there is an increase to values $\sim 1.5 \%$ o lower than background Paleocene values. A core gap from 801.6 to $802.6 \mathrm{~m}$ b.s.f. conceals the end of the recovery phase. Cores 41R-6 and 41R-CC are characterized by the earliest Eocene values, about $0.7 \%$ o lower than the latest Paleocene values. Although no indications for gaps were observed during sampling, the two distinct steps in the $\delta^{13} \mathrm{C}_{\mathrm{TOC}}$ record may indicate very small hiatuses: one at $804.1 \mathrm{~m}$ b.s.f. and one at $803.0 \mathrm{~m}$ b.s.f. (Fig. 2). Paleocene accumulation rates are of the order of $\sim 1.3 \mathrm{~cm} \mathrm{kyr}^{-1}$, based on calcareous nannofossil biostratigraphy (Shafik et al., 1998) and a cyclostratigraphic age model based on variations in total or- ganic carbon (TOC) wt \% (Frieling et al., 2018a). Accumulation rates of $\sim 1 \mathrm{~cm} \mathrm{kyr}^{-1}$ are used for the body of the CIE, although it is important to note that this assumes that the body is complete and between 70 and $100 \mathrm{kyr}$ in duration.

\section{Methods}

All discrete samples taken from the working halves were freeze-dried and measured for bulk magnetic susceptibility before splitting them into fractions for palynology and inorganic and organic geochemical analysis.

\subsection{Bulk magnetic susceptibility}

Freeze-dried samples were weighed and measured for bulk magnetic susceptibility on an MFK1-FA at the paleomagnetism laboratory, Fort Hoofddijk, Utrecht University. Reproducibility was determined with replicate measurements and was always better than $1 \%$.

\subsection{Palynology}

We processed and counted a total of 155 samples, using standard protocols used at the Laboratory of Palaeobotany and Palynology at Utrecht University (Sluijs et al., 2003). In brief, a spike of exotic spores Lycopodium clavatum spores ( $n=20848 \pm 691)$ was added to $1-10 \mathrm{~g}$ of freeze-dried sample to allow for absolute quantitative analysis (Stockmarr, 1971). To dissolve carbonates, sediments were first treated with $10 \% \mathrm{HCl}$, after which supernatants were decanted. This was followed up by two steps of 38-40\% HF and $30 \% \mathrm{HCl}$ to dissolve silicates. Samples were centrifuged and neutralized with tap water before sieving over 250 and $15 \mu \mathrm{m}$ sieves to remove large and small particles, respectively. Subsequently, residues were concentrated in glycerine water and mounted on microscope slides using glycerine jelly. We followed dinocyst taxonomy of Fensome and 


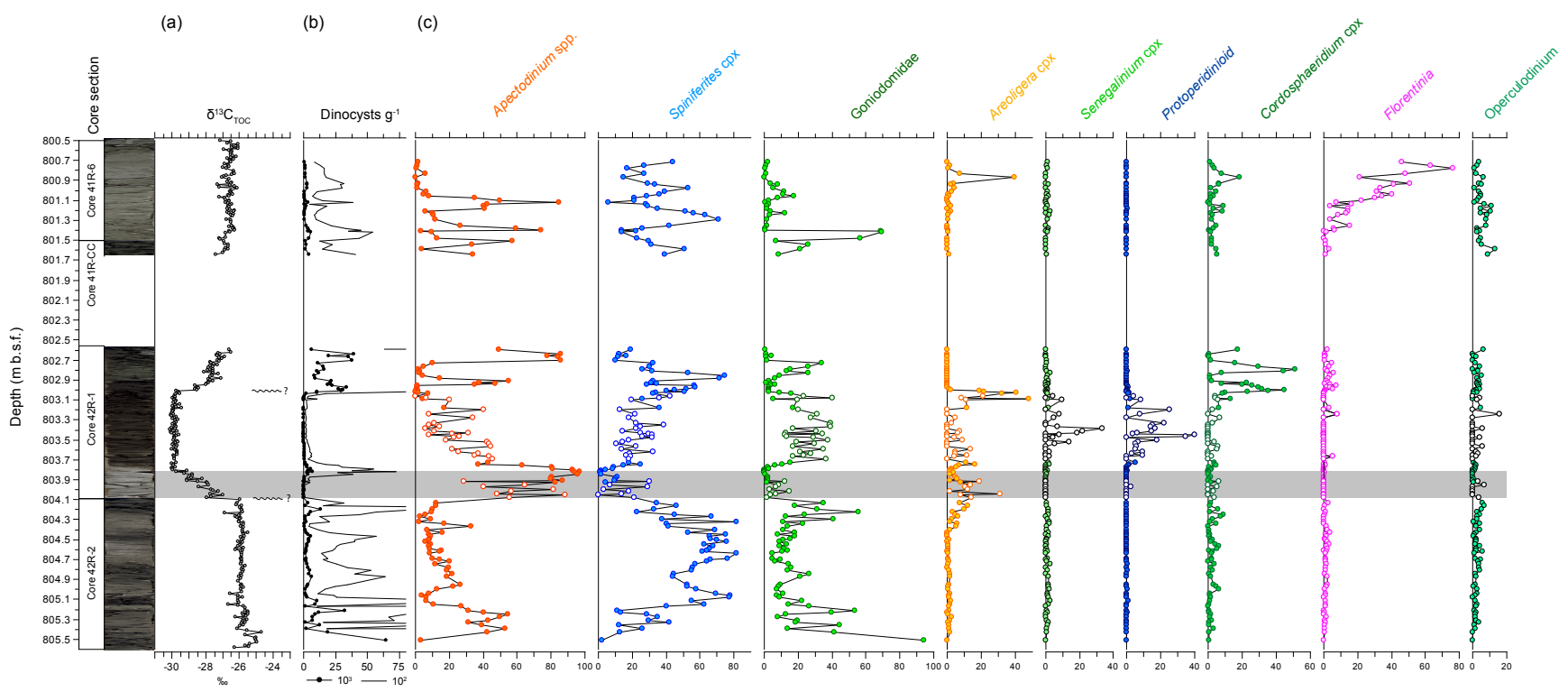

Figure 2. The PETM as recorded by dinoflagellate cyst assemblages at Site 959. (a) $\delta^{13} \mathrm{C}_{\mathrm{TOC}}$ in per mill. (b) Concentration of dinocysts per gram of dry sediment. (c) Dinocyst groups in percentage of total dinocysts. The gray band marks the porcellanite. Symbols in white indicate counts $<100$.

Table 1. Compilation of tropical PETM sites and sites that may show evidence for heat stress. Abbreviations are as follows: sea surface temperature (SST), Ocean Drilling Program (ODP), Tanzania drilling program (TDP).

\begin{tabular}{|c|c|c|c|c|c|}
\hline $\begin{array}{l}\text { Site/section name } \\
\text { (references) }\end{array}$ & $\begin{array}{r}\text { PETM } \\
\text { SST }\left({ }^{\circ} \mathrm{C}\right)\end{array}$ & $\begin{array}{l}\text { SST } \\
\text { proxy }\end{array}$ & $\begin{array}{l}\text { Oceanic } \\
\text { basin }\end{array}$ & $\begin{array}{r}\text { Paleo- } \\
\text { depth }(\mathrm{m})\end{array}$ & Evidence for heat stress? \\
\hline ODP 959 (this study) & 37.4 & $\mathrm{TEX}_{86}^{H}$ & Atlantic & $\sim 1000$ & $\begin{array}{l}\text { Yes, decrease in dinoflagellates, } \\
\text { carbonate, and biosilica }\end{array}$ \\
\hline Dahomey Basin, Nigeria ${ }^{a}$ & 36.1 & $\mathrm{TEX}_{86}^{H}$ & Atlantic & Shelf & $\begin{array}{l}\text { Yes, decrease in dinoflagellates } \\
\text { and mixed-layer foraminifera }\end{array}$ \\
\hline Tanzania TDP14 ${ }^{\mathrm{b}, \mathrm{c}}$ & $>35.4$ & $\delta^{18} \mathrm{O}$ & Indian & Shelf & $\begin{array}{l}\text { Yes, decrease in coccolithophores and } \\
\text { mixed-layer foraminifera }\end{array}$ \\
\hline ODP $1209^{d}$ & 33.5 & $\mathrm{Mg} / \mathrm{Ca}$ & Pacific & $\sim 2000$ & No \\
\hline ODP $865^{\mathrm{e}, \mathrm{f}, \mathrm{g}, \mathrm{h}}$ & 33.2 & $\mathrm{Mg} / \mathrm{Ca} \delta^{18} \mathrm{O}$ & Pacific & $1100-1300$ & No \\
\hline ODP $999 \& 1001^{\mathrm{i}}$ & - & & Atlantic & $1500-2500$ & $\begin{array}{l}\text { Combination of dissolution and } \\
\text { heat stress? }\end{array}$ \\
\hline ODP $1215,1220,1221^{\mathrm{j}}$ & - & & Pacific & $\sim 2500$ & No \\
\hline ODP $1260^{\mathrm{k}}$ & - & & Atlantic & $\sim 2500$ & $\begin{array}{l}\text { Combination of dissolution and } \\
\text { heat stress? }\end{array}$ \\
\hline Multiple sites in Egypt ${ }^{1}$ & - & & Tethys & Shelf/slope & $\begin{array}{l}\text { Ambiguous: mixed-layer foraminifera present, } \\
\text { but no dinoflagellates, diatoms, or pollen }\end{array}$ \\
\hline
\end{tabular}

References: a Frieling et al. (2017). b,c Bown and Pearson (2009); Aze et al. (2014). ${ }^{\text {d }}$ Zachos et al. (2003). e,f, g,h Kelly et al. (1996, 1998); Kozdon et al. (2011); Yamaguchi and Norris (2015). ${ }^{\mathrm{i}}$ Bralower et al. (1997). ${ }^{\mathrm{j}}$ Raffi et al. (2005). ${ }^{\mathrm{k}}$ Mutterlose et al. (2007). ${ }^{\mathrm{l}}$ Speijer and Wagner (2002).

Williams (2004) and the paleoecological grouping of Sluijs and Brinkhuis (2009). Unlike Sluijs and Brinkhuis (2009), we separate Protoperidinioid dinocysts from the other Peridinioid types with hexagonal $2 \mathrm{a}$ archeopyles. Where possible, a minimum of 200 dinocysts were counted. For samples with very low numbers of dinocysts, slides were fully counted to a total of $\sim 10-100$ dinocysts. We estimated the abundance of pyritized remains of biogenic silica relative to organic particles in each sample. A full list of encountered dinocyst taxa is given in Supplement Table S1. All materials are stored in the collection of the Laboratory of Palaeobotany and Palynology, Utrecht University. 


\subsection{XRF core scanning}

XRF Core Scanner data were collected every $1 \mathrm{~cm}$ down-core over a $1 \mathrm{~cm}^{2}$ area with a slit size of $10 \mathrm{~mm}$ using generator settings of 10 and $50 \mathrm{kV}$, a current of 0.2 and $1.0 \mathrm{~mA}$, respectively, and a sampling time of $30 \mathrm{~s}$ directly at the split core surface of the archive halves of core sections 41R-6, 42R-2, and the lower part of 42R-1 with XRF Core Scanner III at the MARUM-University of Bremen. The split core surface was covered with a $4 \mu \mathrm{m}$ SPEX CertiPrep Ultralene foil to avoid contamination of the XRF measurement unit and desiccation of the sediment. The dark-colored interval from 803.8 to $803 \mathrm{~m}$ b.s.f. and directly overlying sediment in core section 42R-1 was too fragmented for acquiring reliable core scanning measurements. The data reported here were acquired using a Canberra X-PIPS Detector (X-PIPS SXP5C-200-1500 from Canberra) with $150 \mathrm{eV}$ X-ray resolution, the Canberra digital spectrum analyzer DAS 1000, and an Oxford Instruments 100W Neptune X-ray tube with rhodium ( $\mathrm{Rh}$ ) target material. Raw data spectra were processed using the "analysis of x-ray spectra by iterative least squares" (WIN AXIL) software package from Canberra Eurisys.

\subsection{Bulk sediment chemistry from inductively coupled plasma optimal emission spectroscopy (ICP-OES)}

Bulk sediment chemistry was determined on 28 samples in the interval that could not be used for XRF core scanning and 22 samples from intervals with XRF scanning data to assess consistency between the two methods. Approximately $125 \mathrm{mg}$ of powdered freeze-dried sediment was dissolved in $2.5 \mathrm{~mL}$ of $\mathrm{HF}(40 \%)$ and $2.5 \mathrm{~mL}$ of a $\mathrm{HClO}_{4} / \mathrm{HNO}_{3}$ mixture in a closed Teflon bomb at $90^{\circ} \mathrm{C}$ during one night. The acids were then evaporated at $160^{\circ} \mathrm{C}$ and the resulting gel was subsequently redissolved in $1 \mathrm{M}$ of $\mathrm{HNO}_{3}$ at $90^{\circ} \mathrm{C}$ during another night. Subsequently, total elemental concentrations were determined with ICP-OES (Perkin Elmer Optima 3000 inductively coupled plasma optimal emission spectroscopy) at Utrecht University. Precision and accuracy was better than $5 \%$, based on calibration to standard solutions and checked against internal laboratory sediment standards. All elemental ratios are normalized to $\mathrm{Al}$, except for organic carbon over total phosphorus $\left(\mathrm{C}_{\text {org }} / \mathrm{P}_{\text {tot }}\right)$, which is reported in moles per mole.

\subsection{Carbonate percentage measurements}

The carbonate concentration of Site 959 samples was determined at the University of Southampton using a UIC CM5015 coulometer operated with a UIC CM5011 emulator and coupled to an AutoMate FX autosampler and carbonate digestion system. The samples were oven-dried at $50^{\circ} \mathrm{C}$, crushed with an agate mortar and pestle, placed in a glass vial, and oven-dried again after crushing. Each vial was capped immediately after removal from the oven to prevent the samples from taking on moisture. Depending on es- timated carbonate content, 10-40 $\mu$ g of bulk dry sample was weighed out on a Sartorius ME5 microbalance and placed in a septum-capped autosampler vial prior to each run. A total of 59 samples were analyzed across six runs on separate days, with repeat analyses performed on $\sim 25 \%$ of the samples. Each run was calibrated using blank-corrected counts for a calcium carbonate standard (Acros Organics, 99.999\% pure) spanning a mass range of $2-10 \mu \mathrm{g}$. External precision is estimated at $\pm 0.6 \% \mathrm{CaCO}_{3}$ based on results from a consistency standard that was included in all runs (average $=73.1 \% ; n=12$ ). The detection limit was determined from a compilation of blank analyses from all runs $(n=24)$, and using the average blank counts plus $3 \times \mathrm{SD}$, the detection limit for a typical $15 \mathrm{mg}$ sample was calculated to be $0.08 \%$ $\mathrm{CaCO}_{3}$.

\section{Results}

\subsection{Palynology}

Dinocysts typically dominate the palynological residues. Pollen and spores derived from terrestrial higher plants are present but in very low abundances (average $\sim 1 \%$; $40 \mathrm{~g}^{-1}$ dry sediment). The body of the PETM CIE and the corresponding interval with higher TOC is marked by high abundances of organic linings of benthic foraminifera (Fig. 3d). Upper Paleocene dinocyst assemblages are composed of three major components (Fig. 2c). The most abundant component is the generalist group Spiniferites, followed by Apectodinium and Goniodomideae with an epicystal archeopyle (hereafter referred to as Goniodomideae; see Sluijs and Brinkhuis, 2009, for taxonomic descriptions of the groups and complexes). Within the uppermost Paleocene, representatives of the Areoligera complex sensu Sluijs and Brinkhuis (2009) increase in abundance. The onset of the PETM is marked by an acme of Apectodinium, reaching the highest abundances ( $>90 \%$ ) between 803.89 and $803.77 \mathrm{~m}$ b.s.f. The body of the CIE yields extremely low abundances of dinocysts $\left(100-200 \mathrm{~g}^{-1}\right)$ so that percentages are based on counts below 200 specimens and should hence be interpreted as rough estimates (open circles in Fig. 2). Regardless, assemblages within the body of the CIE are mostly composed of Goniodomideae, Spiniferites, and Apectodinium. Senegalinium and Protoperidinioid cysts occur almost exclusively within the body of the CIE. High cyst concentrations $\left(>10^{4} \mathrm{~g}^{-1}\right)$ and a series of $\sim 10$ subsequent acmes of different dinocyst groups mark the recovery of the CIE (Fig. 2c). Towards the top of the analyzed interval, Florentinia reichartii becomes the dominant species. Several groups show abundance peaks in the interval following the recovery of the CIE. 


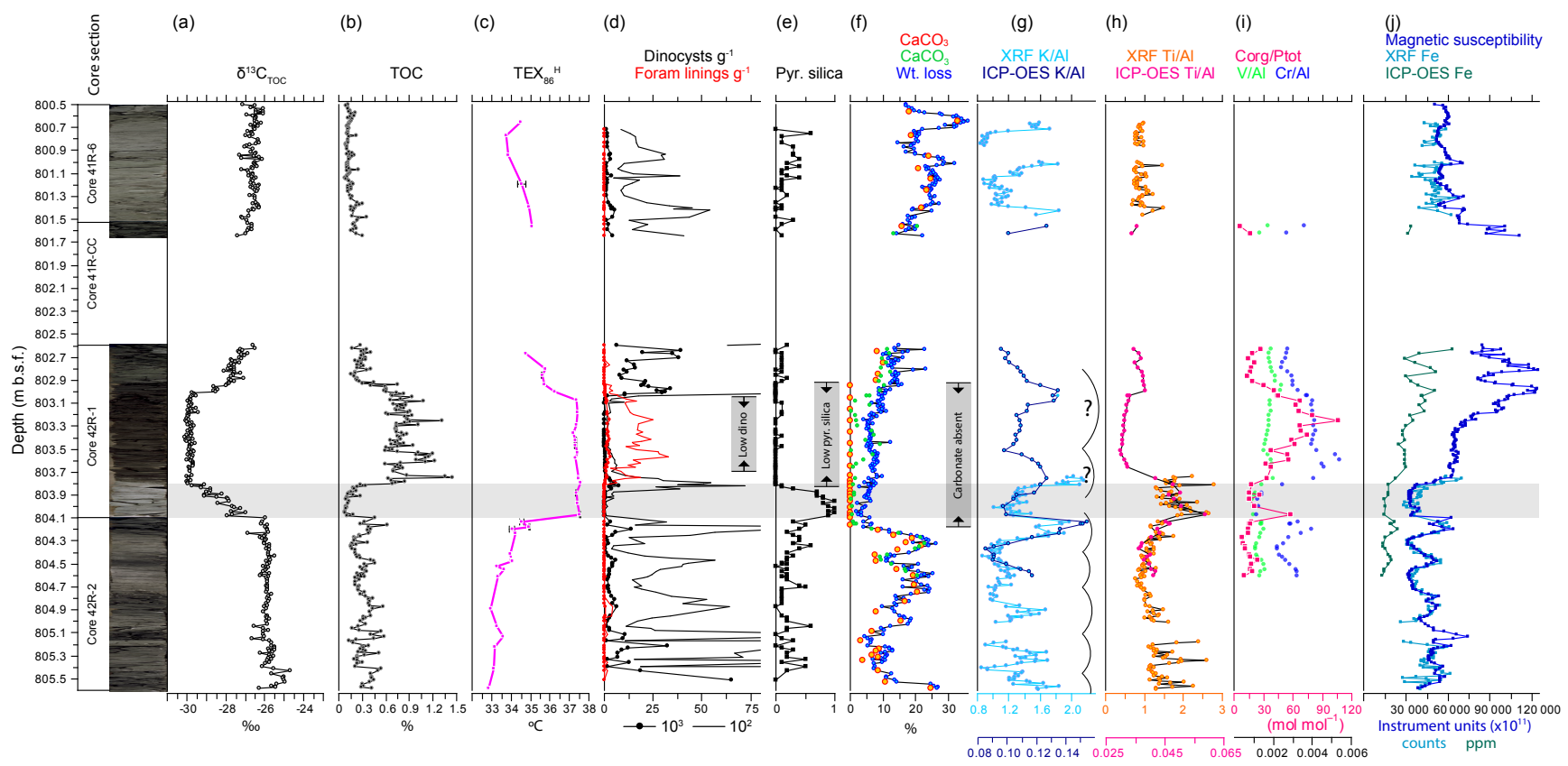

Figure 3. The PETM as recorded with organic and inorganic geochemical proxies at Site 959 . (a) $\delta^{13} \mathrm{C}_{\mathrm{TOC}}$ in per mill. (b) Total organic carbon (TOC) in weight percentages. (c) $\mathrm{TEX}_{86}^{H}$ derived temperature. (d) Dinoflagellate cyst and organic linings of benthic foraminifera ( $\mathrm{g}^{-1}$ of dry sediment, where "n" represents the number of specimens). (e) Fraction of pyritized silica particles in palynological residue. (f) Weight loss during decalcification (wt. loss) as indication of $\mathrm{CaCO}_{3}$ content; $\mathrm{CaCO}_{3}$ calculated from Ca concentration ICP-OES (green) and selected samples analyzed for $\mathrm{CaCO}_{3}$ on a coulometer (orange). (g) K/ Al ratio from XRF (light blue) and ICP (dark blue). (h) Ti / $\mathrm{Al}$ ratio from XRF (orange) and ICP-OES (pink). (i) $\mathrm{Cr} / \mathrm{Al}$ (blue), $\mathrm{V} / \mathrm{Al}$ (light green), and $\mathrm{C}_{\text {org }} / \mathrm{P}_{\text {tot }}$ ratios (pink) in moles per mole. (j) Magnetic susceptibility in instrument units $\left(\times 10^{11}\right.$; dark blue), XRF Fe counts (light blue), and ICP-OES Fe concentrations in parts per million (green). The gray band (804.1-803.83 m b.s.f.) marks the porcellanite. $\delta^{13} \mathrm{C}_{\mathrm{TOC}}$, TOC, and TEX ${ }_{86}^{H}$ data from Frieling et al. (2018a).

\subsection{Carbonate weight \%}

Apart from sediments close to the PETM, the studied interval typically comprises $10-30$ weight $\%$ (wt \%) $\mathrm{CaCO}_{3}$ (Fig. 3f). However, $\mathrm{CaCO}_{3}$ is below the detection limit in an interval starting just below the CIE, at $804.2 \mathrm{~m}$ b.s.f. Various methods, i.e., weight loss during decalcification, $\mathrm{CaCO}_{3}$ based on ICP-OES analysis of $\mathrm{Ca}$ concentrations, and dedicated $\mathrm{CaCO}_{3}$ measurements, show similar trends (Fig. 3f). We use the weight loss during $\mathrm{HCl}$ treatment as a high-resolution approximation for $\mathrm{CaCO}_{3}$ outside the PETM. Especially across the PETM, the weight loss during decalcification is strongly influenced by dissolution of $\mathrm{HCl}$-soluble salts and minerals, especially gypsum, which accounts for 5-10\% of sediment weight in some parts of the CIE.

\subsection{Bulk sediment chemistry (XRF and ICP-OES)}

We use elemental ratios to reconstruct hinterland hydrology and redox-sensitive trace elements to reconstruct bottomwater oxygenation for the site location. The $\mathrm{Ti} / \mathrm{Al}$ ratios from XRF core scanning and ICP-OES analysis show similar trends, with a gradual rise in the upper Paleocene and a second sharp increase at the base of the porcellanite that marks the onset of the CIE (804.1-803.8 m b.s.f., Fig. 3g). Here- after, values drop and remain consistently lower than in the upper Paleocene within the body and recovery phases of the CIE. K / Al ratios correlate well with TOC wt \%. Concentrations are slightly higher within the CIE than in the upper $\mathrm{Pa}$ leocene and are interrupted by a sharp drop in the porcellanite layer. The CIE is also marked by elevated concentrations of $\mathrm{Cr}, \mathrm{S}, \mathrm{Ni}, \mathrm{V}$, and $\mathrm{Zn}$ and progressively higher $\mathrm{C}_{\text {org }} / \mathrm{P}_{\text {tot }}$ ratios $\left(\mathrm{Cr} / \mathrm{Al}, \mathrm{V} / \mathrm{Al}\right.$, and $\mathrm{C}_{\text {org }} / \mathrm{P}_{\text {tot }}$; Fig. 3i).

\subsection{Magnetic susceptibility}

Magnetic susceptibility is anticorrelated with carbonate percentages in the upper Paleocene. At $804.2 \mathrm{~m}$ b.s.f., before the onset of the CIE, this relation disappears. The porcellanite layer is marked by low magnetic susceptibility and the body of the CIE is marked by stable high values. A maximum is reached during the recovery phase, at $802.97 \mathrm{~m}$ b.s.f., followed by a second maximum at $802.81 \mathrm{~m}$ b.s.f. Bulk magnetic susceptibility measurements closely resemble Fe concentrations derived from both ICP-OES and XRF (Fig. 3j) and correlate to TOC wt \% in the upper Paleocene and lower part of the CIE. 


\section{Discussion}

\subsection{Background cyclic variability}

The latest Paleocene at the core location is characterized by cyclic variations in proxy records, including TOC, dinocysts per gram of sediment, magnetic susceptibility, and $\mathrm{CaCO}_{3}$ content (Fig. 3). Frieling et al. (2018a) attributed the cycles to climatic precession ( $21 \mathrm{kyr})$. The implied latest Paleocene average accumulation rates are $\sim 1.3 \mathrm{~cm} \mathrm{kyr}^{-1}$, which is consistent with the available nannofossil biostratigraphy. Cycles may be recorded during the PETM in $\mathrm{K} / \mathrm{Al}$ ratios (Fig. 3g), but these are certainly not unambiguous in other proxy records that show similar cyclic variations in the Paleocene (e.g., TOC wt \% and Fe). However, if these $\mathrm{K} / \mathrm{Al}$ variations also represent precession, it may imply a two-fold increase in accumulation rate. Cyclic variability is notably absent in dinocyst assemblages, $\delta^{13} \mathrm{C}_{\mathrm{TOC}}$, TEX ${ }_{86}^{H}$-derived temperatures, and $\mathrm{Ti} / \mathrm{Al}$ ratios. This observation is important since we can, although with caution, use these as indicators of environmental change that is not associated with background cyclic variability. Anomalies in these parameters can then be used to identify changes in productivity, sea level, or hinterland hydrology, for example, that may be related to the PETM, but not astronomically forced.

\subsection{Depositional setting, sea level, and bottom-water oxygen levels}

\subsubsection{Latest Paleocene background state}

Dinocyst assemblages in the Paleocene are characterized by abundant Spiniferites spp. and Apectodinium spp. Absolute numbers of dinocysts correlate well with TOC wt $\%$, but also with $\mathrm{K} / \mathrm{Al}$ ratio. In tropical regions, $\mathrm{K} / \mathrm{Al}$ ratios vary with wet-dry cycles due to variations in sediment provenance, which suggests that precession forcing may be an important driver of productivity in the study region. We also find that some of the cycles show a "notch" at the peak, which, given the paleolatitude $\left(3-7^{\circ} \mathrm{S}\right)$, may be interpreted to result from the double overpass of the intertropical convergence zone (ITCZ; Verschuren et al., 2009).

Occasionally, Goniodomideae are present in great abundance. In the modern ocean (Zonneveld et al., 2013) and in the Paleogene (Sluijs and Brinkhuis, 2009), high abundances of Goniodomideae occur in very shallow marine settings such as lagoons, and are typically associated with warm, stratified waters and very high and/or seasonally fluctuating salinity. In open ocean settings the group can be indicative of strong stratification (Reichart et al., 2004). Considering the offshore location of Site 959, and relatively low abundances of low-salinity-tolerant taxa, we interpret high abundances of Goniodomideae to indicate seasonally strong stratification, either by temperature or salinity.

From $804.4 \mathrm{~m}$ b.s.f., we find an increase in abundance of dinocysts belonging to, or closely related to, the genus Are- oligera (Areoligera complex sensu; Sluijs and Brinkhuis, 2009). A relative abundance increase in this genus was previously interpreted to reflect sea level rise at several shelf and slope sites during the PETM (Sluijs et al., 2008b). However, Site 959 is located in an open ocean setting, which is reflected in the dinocyst assemblages by the very high relative abundance of Spiniferites, a genus that is relatively more abundant with increasing distance from coastlines in the $\mathrm{Pa}$ leogene and the modern ocean (Brinkhuis, 1994; Pross and Brinkhuis, 2005; Zonneveld et al., 2013).

The PETM is associated with a drop in Areoligera abundance and a concomitant rise in Spiniferites in the relatively offshore locations in New Jersey, such as Bass River (Sluijs and Brinkhuis, 2009), and the Tawanui slope section in New Zealand (Crouch and Brinkhuis, 2005). In the pro-delta settings of ODP Site 1172 on the East Tasman Plateau (Sluijs et al., 2011), the ACEX core in the Arctic Ocean (Sluijs et al., 2008a), and Spitsbergen (Harding et al., 2011), the PETM sees an influx of Areoligera into Paleocene dinocyst assemblages dominated by low-salinity-tolerant Senegalinium, evidencing a more marine setting. In the nearby shelf site in Nigeria, Areoligera is a common constituent of the assemblage only directly before the PETM (Frieling et al., 2017), perhaps recording both the eustatic rise at the PETM and a latest Paleocene regression (Speijer and Morsi, 2002).

Following inferences from previously published records (Sluijs et al., 2008b), higher sea level should hence result in a decrease in the relative abundance of Areoligera at the offshore Site 959. Identifying the cause of this discrepancy is challenging, as the Site 959 record is the first organic-walled dinocyst PETM record from the open ocean. We do not find indications for increased terrestrial input, such as pollen or branched glycerol dialkyl glycerol tetraethers (GDGTs), which could indicate that the signal was transported from the shelf further offshore and this leaves us to assume these specimens are in situ.

However, Goniodomideae, typically associated with stratification (Sluijs et al., 2005; Zonneveld et al., 2013), are abundant lower in the analyzed section and increase in relative abundance together with Areoligera. The abundance of Goniodomideae at more offshore localities is commonly interpreted to result from intense stratification (Reichart et al., 2004) and we propose that abundances of Areoligera may be explained in a similar way. This inference of strong stratification in the region is supported by data from foraminifera and climate model runs, which indicate the presence of a strong but shallow thermocline in the eastern equatorial Atlantic (Frieling et al., 2017). We therefore speculate that the higher percentages of Areoligera here may be related to strong(er) stratification in the latest Paleocene, rather than sea level change. The waters above the thermocline may have emulated the high-energy environment Areoligera prefers (Brinkhuis, 1994; Sluijs and Brinkhuis, 2009). 


\subsubsection{The onset of the PETM and the Apectodinium acme}

The quasi-global acme of the tropical dinocyst genus Apectodinium has long been used as a Paleocene-Eocene boundary marker in biostratigraphic studies (Heilmann-Clausen, 1985; Bujak and Mudge, 1994) and was later discovered to be connected to the PETM (Bujak and Brinkhuis, 1998; Crouch et al., 2001). However, some sections show relatively low percentages of Apectodinium during the PETM (Sluijs et al., 2006; Frieling et al., 2014).

In addition to the acme of Apectodinium, through the entire North Atlantic, Arctic, and northern Tethys, the marker species Apectodinium augustum is present during the PETM (Iakovleva et al., 2001; Schmitz et al., 2004; Sluijs et al., 2006; Sluijs and Brinkhuis, 2009; Harding et al., 2011), although other species are often the dominant representatives of the genus. Recent taxonomic revision of several taxa has removed Apectodinium augustum from Apectodinium and moved it to Axiodinium (Williams et al., 2015). However, we follow the comment of Bijl et al. (2016) and retain A. augustum within the genus of Apectodinium. We consider species within Apectodinium to have similar affinities and continue to refer to the quasi-global abundance event as the Apectodinium acme. A. augustum was not recorded at Site 959.

The abundance of Apectodinium appears to be largely controlled by temperature in higher-latitude regions across the PETM (Crouch et al., 2001; Sluijs et al., 2006; Frieling et al., 2014), but it was abundant to dominant in tropical and subtropical material already in the late Paleocene (Jan du Chêne and Adediran, 1984; Crouch et al., 2003; Sluijs et al., 2014; Frieling et al., 2017) and accounts for $\sim 15 \%$ of the assemblage at Site 959 above $822.14 \mathrm{~m}$ b.s.f. (Awad and Oboh-Ikuenobe, 2016; Fig. 2). Furthermore, the required minimum temperature of $\sim 20^{\circ} \mathrm{C}$ (Frieling et al., 2014) was widespread in many midlatitude sections well before the PETM (Dunkley Jones et al., 2013; Frieling et al., 2017), signaling that other environmental factors were more important in controlling the distribution of Apectodinium at low and midlatitudes (Sluijs et al., 2007a; Sluijs and Brinkhuis, 2009).

At Site 959, Apectodinium is abundantly present in the latest Paleocene, which is not surprising given the equatorial location. This is similar to the Paleocene in Nigeria (Jan du Chêne and Adediran, 1984; Frieling et al., 2017), Cameroon (Mbesse, 2013), and Tunisia (Crouch et al., 2003), indicating that Apectodinium was already common along African margins before the PETM. More surprising is perhaps the general lack of an Apectodinium acme at these low-latitude sites during the PETM, although some caution must be placed due to poor preservation at the Tunisian site (Crouch et al., 2003) and the low sampling resolution of the section in Nigeria (Frieling et al., 2017).

At Site 959, we find the highest abundance $(95 \%)$ of Apectodinium, close to the onset of the body of the PETM
( $803.89 \mathrm{~m}$ b.s.f.). This is perhaps later than at many midlatitude and high-latitude sites where the highest abundance of Apectodinium often slightly precedes the CIE (Sluijs et al., 2007a, 2011; Kender et al., 2012). However, at many of these sites the assemblages are nearly monospecific and we record the same at Site 959. We thus infer this high abundance of Apectodinium to represent the quasi-global Apectodinium acme. The high percentages of Apectodinium in the porcellanite ( $804.1-803.9 \mathrm{~m}$ b.s.f.) are most likely mixed in from above (803.85-803.75 $\mathrm{m}$ b.s.f.), similar to the rest of the organic matter (Frieling et al., 2018a), since assemblages and species are very similar.

\subsubsection{Deoxygenation during the PETM}

Many sites globally show decreased bottom-water oxygen content during the PETM and at some shelf sections bottom waters (Dickson et al., 2012, 2014) and even the photic zone became euxinic (Sluijs et al., 2006, 2014; Frieling et al., 2014, 2017; Schoon et al., 2015). Oxygen minimum zones were expanded (Zhou et al., 2016) and deep ocean waters were affected by deoxygenation, although anoxia did not develop in the deep sea (Chun et al., 2010; Pälike et al., 2014). At Site 959, we find strong indications of decreased oxygen concentrations in bottom waters in the form of increased organic matter burial fluxes, as assessed through reconstructed accumulation rates and TOC wt $\%$. Moreover, increasing $\mathrm{C}_{\text {org }} / \mathrm{P}_{\text {tot }}$ ratios (Fig. 3i) most likely relate to preferential regeneration of phosphorus from sediments under anoxic conditions (Slomp et al., 2002; Algeo and Ingall, 2007). The PETM interval is also associated with slightly elevated concentrations of redox-sensitive elements (e.g., Cr; Fig. 3i). In apparent contrast is an increase in the abundance of organic linings of benthic foraminifera. Some benthic foraminifera, however, tolerate low oxygen concentrations for substantial periods (Langlet et al., 2014) and may outcompete metazoans in such conditions (Woulds et al., 2007). This signal is surprisingly similar to that found in shelf sections of the Gulf of Mexico (Sluijs et al., 2014) and Nigeria (Frieling et al., 2017). The combined information from Site 959 and Nigeria suggests that oxygen minimum zones during the PETM expanded upwards onto the shelf and downwards to the paleodepth of Site 959 (>1000 m) in the eastern tropical Atlantic, a phenomenon very similar to modern trends (e.g., Stramma et al., 2008; Schmidtko et al., 2017).

\subsubsection{Dinocyst decline during peak PETM}

The dinocyst assemblages, but also other microfossil groups, in midlatitudes have been successfully used for detailed environmental reconstructions (e.g., Gibbs et al., 2006; Hollis, 2007; Sluijs and Brinkhuis, 2009; Stassen et al., 2012). Here, we find extremely low numbers of dinocysts $\left(100-200 \mathrm{~g}^{-1}\right.$, relative to latest Paleocene average of $>5000 \mathrm{~g}^{-1}$ ), carbonate and siliceous microfossils during the body of the CIE. Since 
accumulation rates increase by at most a factor of 2 (Fig. 3g), this is appreciably beyond the effect of sediment dilution. Regardless of the cause of eukaryote demise (Sect. 5.4), it hampers a detailed paleoenvironmental reconstruction.

A few dinocyst genera, however, are present. The CIE is notably marked by higher relative abundances of Protoperidinioid cysts, as well as Senegalinium and related genera. Importantly, these are the only groups that increase in relative abundance with respect to the latest Paleocene. Protoperidinioid dinocysts are produced by heterotrophic dinoflagellates in the modern ocean (Jacobson and Anderson, 1986) and most likely also in the Paleogene. Senegalinium cysts were also likely produced by heterotrophic dinoflagellates (Sluijs et al., 2005, 2007a), which implies that a larger proportion of the dinoflagellate production was heterotrophic. This suggests that autotrophic dinoflagellate species were stressed, but that a food source, locally produced or imported from elsewhere, was abundantly present. Notably, based on empirical information, the species in these groups were tolerant to relatively low salinity (Sluijs et al., 2006; Sluijs and Brinkhuis, 2009; Barke et al., 2011). Although lower Ti / Al ratios may indicate hydrological changes in the hinterlands during the body of the CIE (Fig. 3), a large drop in salinity $\sim 150 \mathrm{~km}$ offshore, similar to that seen regionally at proximal sites (e.g., Sluijs and Brinkhuis, 2009; Harding et al., 2011), seems unlikely. Low-salinity-tolerant dinocyst species, i.e., Senegalinium cpx, are abundant in many high-latitude sections during the PETM (Sluijs et al., 2006; Harding et al., 2011), but the high relative abundance of Protoperidinioid cysts is only found at two sites in the eastern equatorial Atlantic (Frieling et al., 2017). This is surprising given the high abundances of Protoperidinioid cysts in sediments deposited in nutrient-rich sectors of the modern ocean. Although other groups are consistently present within the peak of the CIE, absolute numbers are much lower than in the latest Paleocene and we cannot exclude that these specimens are reworked or transported over large distances.

\subsubsection{Recovery of the PETM}

At 803.0 m b.s.f., a small $\left(\sim 1 \%\right.$ ) positive step in $\delta^{13} \mathrm{C}$ possibly indicates a period of nondeposition or erosion, which is followed by the start of the recovery of the CIE. About $\sim 10 \mathrm{~cm}$ above the start of the recovery $(802.9 \mathrm{~m}$ b.s.f.) carbonate accumulation resumes. Dinocyst diversity and abundance, however, recover synchronously with the $\delta^{13} \mathrm{C}$ rise, and even exceed upper Paleocene values. Remarkably, $\sim 10$ distinct acmes of different dinocyst groups occur within $\sim 30 \mathrm{~cm}$ of sediment within the $\sim 100 \mathrm{kyr}$ recovery phase. These events are hence limited to a maximum duration of $10 \mathrm{kyr}$, but are likely much shorter since bioturbation smoothed the signal. Moreover, the recovery of the PETM at Site 959 is truncated by a core gap and perhaps preceded by a small hiatus, which likely leads to underestimated accumulation rates in our approach. Sea surface temperature drops concomitantly with the increase in $\delta^{13} \mathrm{C}$ (Fig. 3) but does not show a clear relation with any of the individual dinocyst groups. While substantial variability is recorded in high-resolution records of other microfossil groups elsewhere (Giusberti et al., 2016), the combination of extremely short-term and high-amplitude extreme biotic variation is unprecedented for any PETM site across the globe, certainly for the recovery interval, and indicates highly variable environmental conditions. We observe high transient abundances of cosmopolitan (Cordosphaeridium) and generalist genera (Spiniferites), species indicative of stratified waters (Goniodomideae), high-energy environments (Areoligera cpx), and Apectodinium (Fig. 2). Although environmental preferences of many of these groups are known, it is difficult and perhaps pointless to disentangle the highly dynamic assemblages into individual environmental signals.

Only the variability of dinocyst assemblages during the body of the CIE at the New Jersey Shelf sites Bass River and Wilson Lake resemble the results at Site 959 (Sluijs and Brinkhuis, 2009). However, Bass River and Wilson Lake are shallower and closer to the paleoshore and therefore more susceptible to environmental swings than the offshore Site 959. The strong variation at Site 959, representing a fully open ocean setting is therefore much more surprising.

Potentially, the recorded variability at Site 959 is related to sub-Milankovitch climate variability, which has been observed in a range of tropical sections from the Proterozoic onwards (Wu et al., 2012; Wilson et al., 2014) and also within the PETM (Abdul Aziz et al., 2008) and in dinocyst records (Reichart and Brinkhuis, 2003). However, we observe no cyclic recurrence of these dinocyst assemblage variations, nor do we find the far more obvious cyclic (precession scale) variation in the upper Paleocene in the dinocyst assemblages. Therefore, this explanation appears unlikely. Unfortunately, none of our proxy records show similar variability in this period; thus, we cannot resolve the underlying cause of such extreme variations in dinocyst assemblages.

\subsubsection{Post PETM assemblages}

Early Eocene dinocyst assemblages and thus presumably environmental circumstances are similar to those found in the Paleocene. Only Florentinia reichartii increases towards the top of the analyzed interval. Although this species seems to be associated with somewhat higher temperatures and freshwater input along the New Jersey shelf (Sluijs and Brinkhuis, 2009), and relates to occurrences of Apectodinium at southwest Pacific ODP Site 1172 (Sluijs et al., 2011), here it thrives under apparently relatively stable, open ocean conditions that prevail in the earliest Eocene. In addition to $F$. reichartii, Apectodinium is occasionally abundant, as are Spiniferites and Goniodomideae. Carbonate content is similar or slightly higher than in the upper Paleocene (10-30\%) and bottom waters appear to be well ventilated. Remarkably, the clear correlations between TOC and dinocyst numbers 
that exists in the upper Paleocene did not return, but dinocyst numbers and $\mathrm{K} / \mathrm{Al}$ ratios continue to show cyclicity at a similar frequency to that in the upper Paleocene, suggesting that the same forcing, possibly precession-driven hydrological changes, remained an important factor governing plankton assemblages at Site 959 (see also Sect. 5.2.1).

\subsection{Absolute temperature and temperature change in a global perspective}

The recorded warming across the onset of the PETM $\left(3.9^{\circ} \mathrm{C}\right)$ is similar to the global average $\left(4-5^{\circ} \mathrm{C}\right.$, e.g., Dunkley Jones et al., 2013; Frieling et al., 2017). However, the few sampled tropical regions typically warmed slightly less (Tripati, 2003; Zachos et al., 2003; Kozdon et al., 2011) than the global average due to persistent extratropical amplification of temperature change (Frieling et al., 2017). The isoprenoid glycerol dialkyl glycerol tetraether (iGDGT) distribution we find here is somewhat similar to modern Red Sea distributions. Within the modern Red Sea, TEX $_{86}$ behaves slightly differently: the relation with temperature has a different slope and is offset from the global calibration (Trommer et al., 2009). The linear Red Sea calibration of Trommer et al. (2009) yields a warming of $3.4{ }^{\circ} \mathrm{C}$, only slightly smaller than the $3.9^{\circ} \mathrm{C}$ recorded by $\mathrm{TEX}_{86}^{H}$, which uses a global calibration dataset (Kim et al., 2010). Furthermore, although iGDGT distributions may look similar, there is no reason to assume that Site 959 was subject to a similar setting or that Thaumarchaeota communities were similar to those in the modern Red Sea. We note that Paleocene $\mathrm{TEX}_{86}^{H}$-reconstructed absolute temperatures are in the same range as those previously reported from this region (Frieling et al., 2017), which are supported by temperature estimates derived from planktonic foraminifer $\delta^{18} \mathrm{O}$ and $\mathrm{Mg} / \mathrm{Ca}$ from the same section. Even though these temperatures are outside the calibration interval $\left(5-30^{\circ} \mathrm{C}\right)$ for $\mathrm{TEX}_{86}^{H}$, the relation with temperature continues to at least $40^{\circ} \mathrm{C}$, based on mesocosm culture experiments (Wuchter et al., 2004; Schouten et al., 2007). Importantly, the maximum temperature that can be reconstructed by $\operatorname{TEX}_{86}^{H}$ is $38.6^{\circ} \mathrm{C}$. The reconstructed temperatures are close to this maximum and we may actually approach the limit of the proxy and underestimate maximum PETM surface-water temperatures (Frieling et al., 2017, 2018a).

\subsection{Heat stress and the demise of eukaryotes}

\subsubsection{Site 959 and Nigerian Shelf}

Sediments typically contain less than $30 \% \mathrm{CaCO}_{3}$ in the latest Paleocene, but already from $804.2 \mathrm{~m}$ b.s.f., just below the onset of the $\mathrm{CIE}, \mathrm{CaCO}_{3}$ is completely absent (Fig. 3f). We explore several factors that might explain this feature. First, similar to Nigeria (Frieling et al. 2017), water column deoxygenation at Site 959 is asynchronous with the demise of dinoflagellates and other microfossil groups and must therefore be decoupled. Second, it could be due to postdeposi- tional carbonate dissolution through PETM ocean acidification as recorded in deep ocean basins (Zachos et al., 2005). However, at no single site described so far, did the carbonate compensation depth (CCD) rise above the reconstructed paleodepth $(\sim 1000 \mathrm{~m}$, Oboh-Ikuenobe et al., 1997) for this site; thus, this scenario seems unlikely. Third, carbonates can be dissolved locally through enhanced oxic organic matter decomposition at the sea floor, producing $\mathrm{CO}_{2}$. However, the dinocyst concentrations $\left(\sim 10^{4} \mathrm{~g}^{-1}\right)$ or TOC $(\sim 0.5 \%)$ content in this interval are not anomalous compared to the entire upper Paleocene; thus, this factor is unlikely the sole explanation. Finally, there may be a general suppression of carbonate (export) production because of biotic stress, either through acidification or warming (Aze et al., 2014; Frieling et al., 2017). We surmise that low carbonate production, possibly associated with the (pre-CIE) warming (Frieling et al., 2018a, Fig. 3c), played a pronounced role in the absence of carbonate throughout the PETM.

After carbonate accumulation ceased, without apparent change in other proxies or large changes in sediment accumulation rates, dinocyst concentrations decreased from 5000 to $100-200 \mathrm{~g}^{-1}$ at $803.70 \mathrm{~m}$ b.s.f. (Fig. 3d). Organic linings of benthic foraminifera continue to increase in abundance, indicating that export productivity did not collapse. This signal is identical to that found in a shelf section from Nigeria (Frieling et al., 2017); both sections show very low (100-200 $\mathrm{g}^{-1}$ ) abundances of dinocysts during peak PETM warmth. We also note that pyritized biogenic silica, which is abundantly present in the upper Paleocene and early Eocene, is largely absent above the porcellanite and only reappears during the recovery (Fig. 3e).

In addition to these overall similarities, the dinocyst assemblages at Site 959 are very similar to those found at the PETM in Nigeria. Both sections are marked by relatively high percentages of Protoperidinioid dinocysts within the body of the PETM, which is an exclusively heterotrophic group (Jacobson and Anderson, 1986). Oxidation experiments show that Protoperidinioid cysts are usually less resistant to oxidation than Spiniferites cysts, for example (Zonneveld et al., 1997, 2008). However, the absence of a relation between the abundance of these taxa and TOC content suggests that preservation is not a major factor. We speculate that these species resided in slightly deeper waters, possibly near the thermocline.

The combined information suggests that eukaryote activity in the mixed layer was suppressed not only in Nigeria (Frieling et al., 2017) but also at the more offshore Site 959. Similar to Nigeria, there is hence no evidence that the low numbers of dinocysts resulted from severe stratification and anoxia, strong variations in salinity, or biases resulting from preservation. Although the initial absence of carbonate is perhaps related to a secondary factor, we attribute the drop in eukaryote production in this region to heat stress, as this is among the few physicochemical factors that can generate the 
same effect in both the open ocean (Site 959) and on the shelf (Nigeria).

It is important to note that primary productivity did not collapse due to the lack of eukaryotes. Organic linings of benthic foraminifera are abundant within the PETM interval at Site 959 and in Nigeria, which suggests that food supply was likely similar to before the PETM. Both sections are characterized by enhanced organic carbon content and burial. This apparently prokaryote-dominated ecosystem, with enhanced organic carbon burial, hence bears some similarities to tropical ecosystems during the Cretaceous ocean anoxic events (OAEs; Kuypers et al., 2001).

\subsubsection{Global tropical heat stress?}

While heat stress seems the most likely option for the demise of eukaryotes in the equatorial Atlantic, other open ocean equatorial and tropical $\left(20^{\circ} \mathrm{S}-20^{\circ} \mathrm{N}\right)$ sites (Table 1) apparently do not show such effects, although some of these records are affected by dissolution and most are devoid of organic carbon. In the tropical and equatorial Pacific (ODP Sites $865,1209,1220$, and 1221) no obvious decrease in calcifying planktic eukaryotes is found during the PETM, but we note that sea surface temperature reconstructions from these sites (Tripati, 2003; Zachos et al., 2003; Kozdon et al., 2011) do not show the excessively high temperatures $\left(>35^{\circ} \mathrm{C}\right.$ ) recorded at Site 959 , Nigeria, or Tanzania (Aze et al., 2014; Frieling et al., 2017). Lower calcium carbonate accumulation at Sites 1209, 1220, and 1221 has been explained by dissolution. Also, the absence of calcium carbonate at sites in the Caribbean and western equatorial Atlantic (ODP Sites 999, 1001, 1258, and 1260) has been attributed to carbonate dissolution (Bralower et al., 1997; Mutterlose et al., 2007). Importantly, however, an influence of heat stress on carbonate production cannot be excluded. In contrast to these relatively deep open ocean sites, the southern Tethyan shelf and slope (Egypt) certainly was not affected by CCD rise. However, the PETM in Egypt is often marked by relatively organic-rich shales mostly devoid of carbonates (Schulte et al., 2011) and yet, as Speijer and Wagner (2002) note, contain no dinocysts, spores, or pollen. These observations could be interpreted as supportive evidence for heat stress among planktic eukaryotes and possibly also land plants (Huber, 2008). Aze et al. (2014) hypothesized that heat-stress effects may have played a role in Tanzania during the PETM as coccolithophores and foraminifera both decline in abundance, and although calcareous dinoflagellate cysts increase in relative abundance, these also remain at very low absolute abundances (Bown and Pearson, 2009). We surmise that heatstress effects during the PETM may not have been limited to the eastern equatorial Atlantic and western Indian Ocean, although it is difficult with the presently available data to disentangle the effects of dissolution, temperature, and other environmental stressors at all potentially affected sites.

\subsection{Potential influence of heat stress on ocean carbonate chemistry}

It is far from certain if heat stress affected planktic calcifiers not only in the eastern equatorial Atlantic and the western Indian Ocean but also in larger areas in the tropics. However, if it did, it might have affected sedimentary sequences in the deep sea to the extent that it had implications for global carbon cycling during the PETM and thus calculations of the mass of carbon that was injected into the ocean-atmosphere system during the PETM (e.g., Panchuk et al., 2008; Zeebe et al., 2009; Luo et al., 2016).

First, it would imply that the reduction in carbonate accumulation rates at tropical sites were potentially a combined result of acidification and heat stress. If so, the reduction in carbonate accumulation across the PETM should have been relatively high at tropical sites relative to higher latitudes (see Sect. 5.4). Interestingly, the reduction in carbonate accumulation was most severe at Walvis Ridge (Zachos et al., 2005) and the Caribbean (Bralower et al., 1997), both located towards the borders of the tropical band, which is in sharp contrast to sustained carbonate deposition in the Atlantic Southern Ocean sites 689 and 690 (Kelly et al., 2005, 2010). Although carbonate wt \% at Pacific tropical sites remains high (Colosimo et al., 2006; Leon-Rodriguez and Dickens, 2010), this is largely due to very low accumulation rates of the sole other sedimentary component, clay, and bioturbation, complicating robust estimates of carbonate accumulation through time.

Second, because calcification consumes alkalinity and produces $\mathrm{CO}_{2}$, heat-stress-limited carbonate production would ultimately act as a negative feedback to acidification following the PETM carbon injection. On a global level, it would ultimately lead to accumulation of alkalinity in ocean water. As such, it could be seen as an indirect, although potentially important, component of so-called biological carbonate compensation: a reduction in carbonate production due to acidification (Luo et al., 2016). This has been invoked as an alternative model to explain the CCD overshoot, i.e., the fact that $\mathrm{CaCO}_{3}$ wt $\%$ within the recovery phase of the PETM exceeds that of the late Paleocene in many deep sea sections (e.g., Luo et al., 2016; Penman et al., 2016).

Collectively, it requires thorough reinterpretation of numerous published records to evaluate to what extent tropical heat stress might have contributed to reduced carbonate accumulation in the global ocean.

\section{Conclusions}

The Paleocene-Eocene transition at Site 959 is marked by a warming of $3.9^{\circ} \mathrm{C}$. Absolute $\mathrm{TEX}_{86}^{H}$ temperatures at $37.4^{\circ} \mathrm{C}$ are unprecedented for the PETM, although they are similar to recent estimates from Nigeria and in good agreement with climate model estimates. 
Importantly, based on our multi-proxy records, we conclude that these extreme temperatures caused a remarkable drop in dinocyst abundances, and most likely also in the production of biogenic carbonate and opal during the PETM. Crucially, only heterotrophic dinoflagellate species, which likely resided somewhat deeper in the water column, persisted. Together with relatively abundant organic benthic foraminifer linings, this indicates sustained primary production, likely dominated by prokaryotes. If the drop in calcification was global, it might have contributed to the recorded decline in deep sea carbonate accumulation, and, as such, it is an important factor to constrain because it potentially affects calculations of global ocean acidification and $\mathrm{CO}_{2}$ input.

Combined evidence from dinocysts and inorganic chemistry points to an altered hydrological cycle at the PETM, resulting in fluctuations in stratification. Furthermore, progressively less oxygenated bottom waters characterize the body phase of the PETM. In sharp contrast to the general absence of eukaryotes during the body phase of the PETM, the recovery phase of the PETM is highly dynamic, with several groups of dinocysts dominating assemblages on timescales shorter than $10 \mathrm{kyr}$.

Data availability. Data used in this publication will be made available through the online database Pangaea (https://doi.org/10.1594/PANGAEA.884760; Frieling et al., 2018b).

\section{The Supplement related to this article is available online at https://doi.org/10.5194/cp-14-39-2018-supplement.}

Author contributions. JF and AS designed the study. JF, SMB, JJM, UR, TW, and GJR performed inorganic geochemical analyses. JF generated palynological data. All authors analyzed and discussed the data. JF and AS wrote the paper, with input from all authors.

Competing interests. The authors declare that they have no conflict of interest.

Acknowledgements. We thank Natasja Welters, Arnold van Dijk, Ton Zalm, and Dominika Kasjaniuk (Utrecht University) for analytical support and Alex Wülbers and Walter Hale (IODP Bremen Core Repository) and Willem Schinkel (Erasmus University Rotterdam) for sampling assistance. The European Research Council (ERC) under the European Union Seventh Framework Program provided funding for this work with ERC starting grant 259627 to Appy Sluijs. The Netherlands Organization for Scientific Research (NWO) supported this work through grant no. 834.11.006 to Gert-Jan Reichart. The Deutsche Forschungsgemeinschaft supported Ursula Röhl and Thomas Westerhold.
This work was carried out under the program of the Netherlands Earth System Science Centre (NESSC), financially supported by the Ministry of Education, Culture and Science (OCW). The International Ocean Discovery Program (IODP) is acknowledged for access to materials and data.

Edited by: Luc Beaufort

Reviewed by: two anonymous referees

\section{References}

Abdul Aziz, H., Hilgen, F. J., van Luijk, G. M., Sluijs, A., Kraus, M. J., Pares, J. M., and Gingerich, P. D.: Astronomical climate control on paleosol stacking patterns in the upper Paleocene-lower Eocene Willwood Formation, Bighorn Basin, Wyoming, Geology, 36, 531-534, https://doi.org/10.1130/G24734A.1, 2008.

Algeo, T. J. and Ingall, E.: Sedimentary Corg:P ratios, paleocean ventilation, and Phanerozoic atmospheric pO2, Palaeogeogr. Palaeocl., 256, 130-155, https://doi.org/10.1016/j.palaeo.2007.02.029, 2007.

Awad, W. K. and Oboh-Ikuenobe, F. E.: Early Paleogene dinoflagellate cysts from ODP Hole 959D, Côte d'Ivoire-Ghana Transform Margin, West Africa: New species, biostratigraphy and paleoenvironmental implications, J. Afr. Earth Sci., 123, 123-144, https://doi.org/10.1016/j.jafrearsci.2016.07.014, 2016.

Aze, T., Pearson, P. N., Dickson, A. J., Badger, M. P. S., Bown, P. R., Pancost, R. D., Gibbs, S. J., Huber, B. T., Leng, M. J., Coe, A. L., Cohen, A. S., and Foster, G. L.: Extreme warming of tropical waters during the Paleocene-Eocene Thermal Maximum, Geology, 42, 739-742, https://doi.org/10.1130/G35637.1, 2014.

Barke, J., Abels, H. A., Sangiorgi, F., Greenwood, D. R., Sweet, A. R., Donders, T., Reichart, G.-J., Lotter, A. F., and Brinkhuis, H.: Orbitally forced Azolla blooms and Middle Eocene Arctic hydrology: Clues from palynology, Geology, 39, 427-430, https://doi.org/10.1130/G31640.1, 2011.

Bijl, P. K., Schouten, S., Sluijs, A., Reichart, G.-J., Zachos, J. C., and Brinkhuis, H.: Early Palaeogene temperature evolution of the southwest Pacific Ocean, Nature, 461, 776-779, https://doi.org/10.1038/nature08399, 2009.

Bijl, P. K., Brinkhuis, H., Egger, L. M., Eldrett, J. S., Frieling, J., Grothe, A., Houben, A. J. P., Pross, J., Śliwińska, K. K., and Sluijs, A.: Comment on " Wetzeliella and its allies - the "hole" story: a taxonomic revision of the Paleogene dinoflagellate subfamily Wetzelielloideae" by Williams et al. (2015), Palynology, 6122, 1-7, https://doi.org/10.1080/01916122.2016.1235056, 2016.

Bown, P. R. and Pearson, P. N.: Calcareous plankton evolution and the Paleocene/Eocene thermal maximum event: new evidence from Tanzania, Mar. Micropaleontol., 71, 60-70, 2009.

Bralower, T. J., Thomas, D. J., Zachos, J. C., Hirschmann, M. M., Röhl, U., Sigurdsson, H., Thomas, E., and Whitney, D. L.: High-resolution records of the late Paleocene thermal maximum and circum-Caribbean volcanism: Is there a causal link?, Geology, 25, 963-966, https://doi.org/10.1130/00917613(1997)025<0963:HRROTL>2.3.CO;2, 1997.

Brinkhuis, H.: Late Eocene to Early Oligocene dinoflagellate cysts from the Priabonian type-area (northeast Italy): Biostratigraphy and paleoenvironmental interpretation, Palaeogeogr. Palaeocl., 107, 121-163, 1994. 
Bujak, J. P. and Brinkhuis, H.: Global warming and dinocyst changes across the Paleocene/Eocene epoch boundary, edited by: Aubry, M.-P., Lucas, S., and Berggren, W. A., Late Paleoceneearly Eocene biotic and climatic events in the marine and terrestrial records: New York, Columbia University Press, 277-295, 1998.

Bujak, J. P. and Mudge, D. C.: A high-resolution North Sea Eocene dinocyst zonation, J. Geol. Soc. London., 151, 449-462, 1994.

Carmichael, M. J., Inglis, G. N., Badger, M. P. S., Naafs, B. D. A., Behrooz, L., Remmelzwaal, S., Monteiro, F. M., Rohrssen, M., Farnsworth, A., Buss, H. L., Dickson, A. J., Valdes, P. J., Lunt, D. J., and Pancost, R. D.: Hydrological and associated biogeochemical consequences of rapid global warming during the PaleoceneEocene Thermal Maximum, Global Planet. Change, 157, 114138, https://doi.org/10.1016/j.gloplacha.2017.07.014, 2017.

Chun, C. O. J., Delaney, M. L., and Zachos, J. C.: Paleoredox changes across the Paleocene-Eocene thermal maximum, Walvis Ridge (ODP Sites 1262, 1263, and 1266): Evidence from $\mathrm{Mn}$ and $\mathrm{U}$ enrichment factors, Paleoceanography, 25, 1-13, https://doi.org/10.1029/2009PA001861, 2010.

Colosimo, A. B., Bralower, T. J., and Zachos, J. C.: Evidence for lysocline shoaling at the Paleocene/Eocene thermal maximum on Shatsky Rise, northwest Pacific, in Proceedings of the Ocean Drilling Program, Scientific Results, 198, 1-36, College Station Texas, 2006.

Cramwinckel, M. J., Kocken, I. J., Agnini, C., Huber, M., van der Ploeg, R., Frieling, J., Bijl, P. K., Peterse, F., Rohl, U., Bohaty, S. M., Schouten, S., and Sluijs, A.: Synchronous tropical and deep ocean temperature evolution in the Eocene, Nature, in revision, 2018.

Crouch, E. M. and Brinkhuis, H.: Environmental change across the Paleocene-Eocene transition from eastern New Zealand: a marine palynological approach, Mar. Micropaleontol., 56, 138-160, 2005.

Crouch, E. M., Heilmann-Clausen, C., Brinkhuis, H., Morgans, H. E. G., Rogers, K. M., Egger, H., and Schmitz, B.: Global dinoflagellate event associated with the late Paleocene thermal maximum, Geology, 29, 315-318, 2001.

Crouch, E. M., Brinkhuis, H., Visscher, H., Adatte, T., and Bolle, M.-P.: Late Paleocene-early Eocene dinoflagellate cyst records from the Tethys: Further observations on the global distribution of Apectodinium, Spec. Pap. Geol. Soc. Am., 369, 113-131, https://doi.org/10.1130/0-8137-2369-8.113, 2003.

Dickens, G. R.: Down the Rabbit Hole: toward appropriate discussion of methane release from gas hydrate systems during the Paleocene-Eocene thermal maximum and other past hyperthermal events, Clim. Past, 7, 831-846, https://doi.org/10.5194/cp7-831-2011, 2011.

Dickens, G. R., O’Neil, J. R., Rea, D. K., and Owen, R. M.: Dissociation of oceanic methane hydrate as a cause of the carbon isotope excursion at the end of the Paleocene, Paleoceanography, 10, 965-971, https://doi.org/10.1029/95PA02087, 1995.

Dickson, A. J., Cohen, A. S., and Coe, A. L.: Seawater oxygenation during the Paleocene-Eocene Thermal Maximum, Geology, 40, 639-642, https://doi.org/10.1130/G32977.1, 2012.

Dickson, A. J., Rees-Owen, R. L., März, C., Coe, A. L., Cohen, A. S., Pancost, R. D., Taylor, K., and Shcherbinina, E.: The spread of marine anoxia on the northern Tethys margin dur- ing the Paleocene-Eocene Thermal Maximum, Paleoceanography, 29, 471-488, https://doi.org/10.1002/2014PA002629, 2014.

Doney, S. C., Ruckelshaus, M., Duffy, J. E., Barry, J. P., Chan, F., English, C. A., Galindo, H. M., Grebmeier, J. M., Hollowed, A. B., and Knowlton, N.: Climate change impacts on marine ecosystems, Mar. Sci., 4, https://doi.org/10.1146/annurevmarine-041911-111611, 2012.

Dunkley Jones, T., Lunt, D. J., Schmidt, D. N., Ridgwell, A. J., Sluijs, A., Valdes, P. J., and Maslin, M. A.: Climate model and proxy data constraints on ocean warming across the PaleoceneEocene Thermal Maximum, Earth-Sci. Rev., 125, 123-145, https://doi.org/10.1016/j.earscirev.2013.07.004, 2013.

Fensome, R. A. and Williams, G. L.: The Lentin and Williams Index of Fossil Dinoflagellates 2004 Edition, 909 pp., Am. Assoc. Strat. Coll. Station. Tex, 2004.

Frieling, J., Iakovleva, A. I., Reichart, G.-J., Aleksandrova, G. N., Gnibidenko, Z. N., Schouten, S., and Sluijs, A.: PaleoceneEocene warming and biotic response in the epicontinental West Siberian Sea, Geology, 42, 767-770, 2014.

Frieling, J., Svensen, H. H., Planke, S., Cramwinckel, M. J., Selnes, H., and Sluijs, A.: Thermogenic methane release as a cause for the long duration of the PETM, P. Natl. Acad. Sci. USA, 113, 12059-12064, https://doi.org/10.1073/pnas.1603348113, 2016.

Frieling, J., Gebhardt, H., Huber, M., Adekeye, O. A., Akande, S. O., Reichart, G.-J., Middelburg, J. J., Schouten, S., and Sluijs, A.: Extreme warmth and heat-stressed plankton in the tropics during the Paleocene-Eocene Thermal Maximum, Sci. Adv., 3, e1600891, https://doi.org/10.1126/sciadv.1600891, 2017.

Frieling, J., Peterse, F., Lunt, D. J., Bohaty, S. M., Sinninghe Damsté, J. S., Reichart, G.-J., and Sluijs, A.: A smoking gun for methane hydrate release during the Paleocene-Eocene Thermal Maximum, under review, Paleoceanogr. Paleocl., 2018a.

Frieling, J., Reichart, G.-J., Middelburg, J., Röhl, U., Westerhold, T., Bohaty, S., and Sluijs, A.: 959D PETM Dinoflagellate cyst assemblages and other data files, https://doi.org/10.1594/PANGAEA.884760, 2018b.

Gibbs, S. J., Bralower, T. J., Bown, P. R., Zachos, J. C., and Bybell, L. M.: Shelf and open-ocean calcareous phytoplankton assemblages across the Paleocene-Eocene Thermal Maximum: Implications for global productivity gradients, Geology, 34, 233-236, https://doi.org/10.1130/G22381.1, 2006.

Giusberti, L., Boscolo Galazzo, F., and Thomas, E.: Variability in climate and productivity during the Paleocene-Eocene Thermal Maximum in the western Tethys (Forada section), Clim. Past, 12, 213-240, https://doi.org/10.5194/cp-12-213-2016, 2016.

Handley, L., O’Halloran, A., Pearson, P. N., Hawkins, E., Nicholas, C. J., Schouten, S., McMillan, I. K., and Pancost, R. D.: Changes in the hydrological cycle in tropical East Africa during the Paleocene-Eocene Thermal Maximum, Palaeogeogr. Palaeocl., 329-330, 10-21, https://doi.org/10.1016/j.palaeo.2012.02.002, 2012.

Harding, I. C., Charles, A. J., Marshall, J. E. A., Pälike, H., Roberts, A. P., Wilson, P. A., Jarvis, E., Thorne, R., Morris, E., Moremon, R., Pearce, R. B., and Akbari, S.: Sea-level and salinity fluctuations during the Paleocene-Eocene thermal maximum in Arctic Spitsbergen, Earth Planet. Sc. Lett., 303, 97-107, https://doi.org/10.1016/j.eps1.2010.12.043, 2011. 
Heilmann-Clausen, C.: Dinoflagellate stratigraphy of the uppermost Danian to Ypresian in the Viborg 1 borehole, central Jylland, Denmark, I Kommission hos CA Reitzels forlag, 1985.

Hoins, M., Van de Waal, D. B., Eberlein, T., Reichart, G.-J., Rost, B., and Sluijs, A.: Stable carbon isotope fractionation of organic cyst-forming dinoflagellates: Evaluating the potential for a CO2 proxy, Geochim. Cosmochim. Ac., 160, 267-276, https://doi.org/10.1016/j.gca.2015.04.001, 2015.

Hollis, C. J.: Radiolarian faunal turnover through the Paleoceneeocene transition, Mead Stream, New Zealand, in Radiolaria, 7999, Springer, 2007.

Hollis, C. J., Taylor, K. W. R., Handley, L., Pancost, R. D., Huber, M., Creech, J. B., Hines, B. R., Crouch, E. M., Morgans, H. E. G., Crampton, J. S., Gibbs, S., Pearson, P. N., and Zachos, J. C.: Early Paleogene temperature history of the Southwest Pacific Ocean: Reconciling proxies and models, Earth Planet. Sc. Lett., 349-350, 53-66, https://doi.org/10.1016/j.epsl.2012.06.024, 2012.

Huber, M.: A Hotter Greenhouse?, Science, 321, 353-354, https://doi.org/10.1126/science.1161170, 2008.

Iakovleva, A. I., Brinkhuis, H., and Cavagnetto, C.: Late Palaeocene-Early Eocene dinoflagellate cysts from the Turgay Strait, Kazakhstan; correlations across ancient seaways, Palaeogeogr. Palaeocl., 172, 243-268, 2001.

Jacobson, D. M. and Anderson, D. M.: Thecate Heterotrophic Dinoflagellates: Feeding Behavior and Mechanisms, J. Phycol., 22, 249-258, 1986.

Jan du Chêne, R. and Adediran, S. A.: Late Paleocene to early Eocene dinoflagellates from Nigeria, Cah. Micropaléontologie, 3, 5-38, 1984.

Kelly, D. C., Bralower, T. J., Zachos, J. C., Silva, P., Thomas, E., I, Silva, I. P., and Thomas, E.: Rapid diversification of planktonic foraminifera in the tropical Pacific (ODP Site 865) during the late Paleocene thermal maximum, Geology, 24, 423-426, https://doi.org/10.1130/00917613(1996)024<0423:RDOPFI>2.3.CO, 1996.

Kelly, D. C., Bralower, T. J., and Zachos, J. C.: Evolutionary consequences of the latest Paleocene thermal maximum for tropical planktonic foraminifera, Palaeogeogr. Palaeocl., 141, 139-161, https://doi.org/10.1016/S0031-0182(98)00017-0, 1998.

Kelly, D. C., Zachos, J. C., Bralower, T. J., and Schellenberg, S. A.: Enhanced terrestrial weathering/runoff and surface ocean carbonate production during the recovery stages of the Paleocene-Eocene thermal maximum, Paleoceanography, 20, 111, https://doi.org/10.1029/2005PA001163, 2005.

Kelly, D. C., Nielsen, T. M. J., McCarren, H. K., Zachos, J. C., and Röhl, U.: Spatiotemporal patterns of carbonate sedimentation in the South Atlantic: Implications for carbon cycling during the Paleocene-Eocene thermal maximum, Palaeogeogr. Palaeocl., 293, 30-40, https://doi.org/10.1016/j.palaeo.2010.04.027, 2010.

Kender, S., Stephenson, M. H., Riding, J. B., Leng, M. J., Knox, R. W. O. B., Peck, V. L., Kendrick, C. P., Ellis, M. A., Vane, C. H., and Jamieson, R.: Marine and terrestrial environmental changes in NW Europe preceding carbon release at the Paleocene-Eocene transition, Earth Planet. Sc. Lett., 353-354, 108-120, https://doi.org/10.1016/j.epsl.2012.08.011, 2012.

Kim, J. H., van der Meer, J., Schouten, S., Helmke, P., Willmott, V., Sangiorgi, F., Koç, N., Hopmans, E. C., and Sinninghe Damsté, J. S.: New indices and calibrations derived from the distribution of crenarchaeal isoprenoid tetraether lipids: Implications for past sea surface temperature reconstructions, Geochim. Cosmochim. Ac., 74, 4639-4654, https://doi.org/10.1016/j.gca.2010.05.027, 2010.

Kirtland Turner, S. and Ridgwell, A.: Development of a novel empirical framework for interpreting geological carbon isotope excursions, with implications for the rate of carbon injection across the PETM, Earth Planet. Sc. Lett., 435, 1-13, https://doi.org/10.1016/j.epsl.2015.11.027, 2016.

Kozdon, R., Kelly, D. C., Kita, N. T., Fournelle, J. H., and Valley, J. W.: Planktonic foraminiferal oxygen isotope analysis by ion microprobe technique suggests warm tropical sea surface temperatures during the Early Paleogene, Paleoceanography, 26, 1-17, https://doi.org/10.1029/2010PA002056, 2011.

Kuypers, M. M. M., Blokker, P., Erbacher, J., Kinkel, H., Pancost, R. D., Schouten, S., and Sinninghe Damsté, J. S.: Massive Expansion of Marine Archaea During a MidCretaceous Oceanic Anoxic Event, Science, 293, 92-95, https://doi.org/10.1126/science.1058424, 2001.

Langlet, D., Baal, C., Geslin, E., Metzger, E., Zuschin, M., Riedel, B., Risgaard-Petersen, N., Stachowitsch, M., and Jorissen, F. J.: Foraminiferal species responses to in situ, experimentally induced anoxia in the Adriatic Sea, Biogeosciences, 11, 17751797, https://doi.org/10.5194/bg-11-1775-2014, 2014.

Leon-Rodriguez, L. and Dickens, G. R.: Constraints on ocean acidification associated with rapid and massive carbon injections: The early Paleogene record at ocean drilling program site 1215, equatorial Pacific Ocean, Palaeogeogr. Palaeocl., 298, 409-420, https://doi.org/10.1016/j.palaeo.2010.10.029, 2010.

Littler, K., Röhl, U., Westerhold, T., and Zachos, J. C.: A highresolution benthic stable-isotope record for the South Atlantic: Implications for orbital-scale changes in Late Paleocene-Early Eocene climate and carbon cycling, Earth Planet. Sc. Lett., 401, 18-30, 2014.

Luo, Y., Boudreau, B. P., Dickens, G. R., Sluijs, A., and Middelburg, J. J.: An alternative model for $\mathrm{CaCO} 3$ over-shooting during the PETM: Biological carbonate compensation, Earth Planet. Sc. Lett., 453, 223-233, https://doi.org/10.1016/j.eps1.2016.08.012, 2016.

Mbesse, C. O.: La limite Paléocène-Eocène dans le Bassin de Douala Biostratigraphie et essai de reconstitution des paléoenvironnements, 2013.

McInerney, F. A. and Wing, S. L.: The Paleocene-Eocene thermal maximum: a perturbation of carbon cycle, climate, and biosphere with implications for the future, Annu. Rev. Earth Planet. Sc., 39, 489-516, 2011.

Murphy, B. H., Farley, K., and Zachos, J. C.: An extraterrestrial 3 He-based timescale for the Paleocene-Eocene thermal maximum (PETM) from Walvis Ridge, IODP Site 1266, Geochim. Cosmochim. Ac., 74, 5098-5108, 2010.

Mutterlose, J., Linnert, C., and Norris, R. D.: Calcareous nannofossils from the Paleocene-Eocene Thermal Maximum of the equatorial Atlantic (ODP Site 1260B): evidence for tropical warming, Mar. Micropaleontol., 65, 13-31, 2007.

Oboh-Ikuenobe, F. E., Yepes, O., Mascle, J., Lohmann, G. P., Clift, P., Akamaluk, T., Allerton, S., Ask, M., Barrera, E., Barton, E., Basile, C., Bellier, J. P., Benkhelil, J., Brantuoh, E., Edwards, R., Ewert, E., Gonçalves, C., Janik, A. G., Holmes, M. A., Hisada, K. I., Lohmann, K. C., Morita, S., Montera-Gutierrez, C. A., Norris, 
R. D., Pletsch, T., Pickett, E. A., Ravizza, G., Shafik, S., Shin, I. C., Strand, K. O., Wagner, T., and Watkins, D. K.: Palynofacies analysis of sediments from the Cote d'Ivoire-Ghana Transform Margin: Preliminary correlation with some regional events in the Equatorial Atlantic, Palaeogeogr. Palaeocl., 129, 291-314, https://doi.org/10.1016/S0031-0182(96)00125-3, 1997.

Pagani, M., Pedentchouk, N., Huber, M., Sluijs, A., Schouten, S., Brinkhuis, H., Sinninghe Damsté, J. S., and Dickens, G. R.: Arctic hydrology during global warming at the Palaeocene/Eocene thermal maximum, Nature, 442, 671-675, https://doi.org/10.1038/nature05043, 2006.

Pälike, C., Delaney, M. L., and Zachos, J. C.: Deep-sea redox across the Paleocene-Eocene thermal maximum, Geochem. Geophy. Geosy., 15, 1038-1053, https://doi.org/10.1002/2013GC005074, 2014.

Panchuk, K., Ridgwell, A. J., and Kump, L. R.: Sedimentary response to Paleocene-Eocene Thermal Maximum carbon release: A model-data comparison, Geology, 36, 315-318, https://doi.org/10.1130/G24474A.1, 2008.

Pandolfi, J. M., Connolly, S. R., Marshall, D. J., and Cohen, A. L.: Projecting coral reef futures under global warming and ocean acidification, Science, 333, 418-422, https://doi.org/10.1126/science.1204794, 2011.

Penman, D. E., Turner, S. K., Sexton, P. F., Norris, R. D., Dickson, A. J., Boulila, S., Ridgwell, A., Zeebe, R. E., Zachos, J. C., Cameron, A., Westerhold, T., and Röhl, U.: An abyssal carbonate compensation depth overshoot in the aftermath of the Palaeocene-Eocene Thermal Maximum, Nat. Geosci., 9, 575580, https://doi.org/10.1038/ngeo2757, 2016.

Pross, J. and Brinkhuis, H.: Organic-walled dinoflagellate cysts as paleoenvironmental indicators in the Paleogene?; a synopsis of concepts, Paläontologische Zeitschrift, 79, 53-59, 2005.

Raffi, I., Backman, J., and Pälike, H.: Changes in calcareous nannofossil assemblages across the Paleocene/Eocene transition from the paleo-equatorial Pacific Ocean, Palaeogeogr. Palaeocl., 226, 93-126, 2005.

Reichart, G.-J. and Brinkhuis, H.: Late Quaternary Protoperidinium cysts as indicators of paleoproductivity in the northern Arabian Sea, Mar. Micropaleontol., 49, 303-315, 2003.

Reichart, G.-J., Brinkhuis, H., Huiskamp, F., and Zachariasse, W. J.: Hyperstratification following glacial overturning events in the northern Arabian Sea, Paleoceanography, 19, PA2013, https://doi.org/10.1029/2003PA000900, 2004.

Röhl, U., Westerhold, T., Bralower, T. J., and Zachos, J. C.: On the duration of the Paleocene-Eocene thermal maximum (PETM), Geochem. Geophy. Geosy., 8, 1-13, https://doi.org/10.1029/2007GC001784, 2007.

Schmidtko, S., Stramma, L., and Visbeck, M.: Decline in global oceanic oxygen content during the past five decades, Nature, 542, 335-339, https://doi.org/10.1038/nature21399, 2017.

Schmitz, B. and Pujalte, V.: Abrupt increase in seasonal extreme precipitation at the Paleocene-Eocene boundary, Geology, 35, 215-218, https://doi.org/10.1130/G23261A.1, 2007.

Schmitz, B., Peucker-Ehrenbrink, B., Heilmann-Clausen, C., Aberg, G., Asaro, F., and Lee, C.-T. A.: Basaltic explosive volcanism, but no comet impact, at the Paleocene-Eocene boundary: high-resolution chemical and isotopic records from Egypt, Spain and Denmark, Earth Planet. Sc. Lett., 225, 1-17, https://doi.org/10.1016/j.epsl.2004.06.017, 2004.
Schoon, P. L., Heilmann-Clausen, C., Schultz, B. P., Sinninghe Damsté, J. S., and Schouten, S.: Warming and environmental changes in the eastern North Sea Basin during the Palaeocene-Eocene Thermal Maximum as revealed by biomarker lipids, Org. Geochem., 78, 79-88, https://doi.org/10.1016/j.orggeochem.2014.11.003, 2015.

Schouten, S., Forster, A., Panoto, F. E., and Sinninghe Damsté, J. S.: Towards calibration of the TEX 86 palaeothermometer for tropical sea surface temperatures in ancient greenhouse worlds, Org. Geochem., 38, 1537-1546, https://doi.org/10.1029/2004PA001041, 2007.

Schulte, P., Scheibner, C., and Speijer, R. P.: Fluvial discharge and sea-level changes controlling black shale deposition during the Paleocene-Eocene Thermal Maximum in the Dababiya Quarry section, Egypt, Chem. Geol., 285, 167-183, 2011.

Seton, M., Müller, R. D., Zahirovic, S., Gaina, C., Torsvik, T. H., Shephard, G., Talsma, A., Gurnis, M., Turner, M., and Maus, S.: Global continental and ocean basin reconstructions since 200Ma, Earth-Sci. Rev., 113, 212-270, 2012.

Shafik, S., Watkins, D. K., and Shin, I. C.: 32 . Calcareous Nannofossil Paleogene Biostratigraphy, Côte D' Ivoire-Ghana, Proc. Ocean Drill. Program, Sci. Results, 159, 413-431, 1998.

Shipboard Science Party: Site 959, Mascle, J., Lohmann, GP, Clift, PD, al., Proc. ODP, Init. Repts, 159, 65-150, 1996.

Slomp, C. P., Thomson, J., and De Lange, G. J.: Enhanced regeneration of phosphorus during formation of the most recent eastern Mediterranean sapropel (S1), Geochim. Cosmochim. Ac., 66, 1171-1184, https://doi.org/10.1016/S0016-7037(01)008481,2002

Sluijs, A. and Brinkhuis, H.: A dynamic climate and ecosystem state during the Paleocene-Eocene Thermal Maximum: inferences from dinoflagellate cyst assemblages on the New Jersey Shelf, Biogeosciences, 6, 1755-1781, https://doi.org/10.5194/bg-61755-2009, 2009.

Sluijs, A. and Dickens, G. R.: Assessing offsets between the $\delta 13 \mathrm{C}$ of sedimentary components and the global exogenic carbon pool across early Paleogene carbon cycle perturbations, Global Biogeochem. Сy., 26, 1-14, https://doi.org/10.1029/2011GB004224, 2012.

Sluijs, A., Brinkhuis, H., Stickley, C. E., Warnaar, J., Williams, G. L., and Fuller, M.: Dinoflagellate cysts from the Eocene/Oligocene transition in the Southern Ocean; results from ODP Leg 189, in Proc. Ocean Drill. Program Sci. Results, 189, 1-42, 2003.

Sluijs, A., Pross, J., and Brinkhuis, H.: From greenhouse to icehouse; organic-walled dinoflagellate cysts as paleoenvironmental indicators in the Paleogene, Earth-Sci. Rev., 68, 281-315, https://doi.org/10.1016/j.earscirev.2004.06.001, 2005.

Sluijs, A., Schouten, S., Pagani, M., Woltering, M., Brinkhuis, H., Sinninghe Damsté, J. S., Dickens, G. R., Huber, M., Reichart, G.-J., Stein, R., Matthiessen, J., Lourens, L. J., Pedentchouk, N., Backman, J., Moran, K., and the Expedition, S.: Subtropical Arctic Ocean temperatures during the Palaeocene/Eocene thermal maximum, Nature, 441, 610-613, https://doi.org/10.1038/nature04668, 2006.

Sluijs, A., Brinkhuis, H., Schouten, S., Bohaty, S. M., John, C. M., Zachos, J. C., Reichart, G.-J., Sinninghe Damsté, J. S., Crouch, E. M., and Dickens, G. R.: Environmental precursors to rapid light carbon injection at the Palaeocene/Eocene boundary, 
Nature, 450, 1218-1221, https://doi.org/10.1038/nature06400, $2007 \mathrm{a}$.

Sluijs, A., Bowen, G. J., Brinkhuis, H., Lourens, L. J., and Thomas, E.: The Palaeocene-Eocene Thermal Maximum super greenhouse: Biotic and geochemical signatures, age models and mechanisms of global change, Geol. Soc. Spec. Publ., 323-349, $2007 b$.

Sluijs, A., Röhl, U., Schouten, S., Brumsack, H. J., Sangiorgi, F., Sinninghe Damsté, J. S., and Brinkhuis, H.: Article late Paleocene - Early Eocene paleoenvironments with special emphasis on the Paleocene-Eocene thermal maximum (Lomonosov Ridge, Integrated Ocean Drilling Program Expedition 302), Paleoceanography, 23, PA1S11, https://doi.org/10.1029/2007PA001495, 2008a.

Sluijs, A., Brinkhuis, H., Crouch, E. M., John, C. M., Handley, L., Munsterman, D., Bohaty, S. M., Zachos, J. C., Reichart, G. J., Schouten, S., Pancost, R. D., Sinninghe Damsté, J. S., Welters, N. L. D., Lotter, A. F., and Dickens, G. R.: Eustatic variations during the Paleocene-Eocene greenhouse world, Paleoceanography, 23, 1-18, https://doi.org/10.1029/2008PA001615, 2008b.

Sluijs, A., Bijl, P. K., Schouten, S., Röhl, U., Reichart, G.-J., and Brinkhuis, H.: Southern ocean warming, sea level and hydrological change during the Paleocene-Eocene thermal maximum, Clim. Past, 7, 47-61, https://doi.org/10.5194/cp-7-472011, 2011.

Sluijs, A., Van Roij, L., Harrington, G. J., Schouten, S., Sessa, J. A., Levay, L. J., Reichart, G.-J., and Slomp, C. P.: Warming, euxinia and sea level rise during the paleocene-eocene thermal maximum on the gulf coastal plain: Implications for ocean oxygenation and nutrient cycling, Clim. Past, 10, 1421-1439, https://doi.org/10.5194/cp-10-1421-2014, 2014.

Speijer, R. P. and Morsi, A.-M. M.: Ostracode turnover and sea-level changes associated with the Paleocene-Eocene thermal maximum, Geology, 30, 23-26, 2002.

Speijer, R. P. and Wagner, T.: Sea-level changes and black shales associated with the late Paleocene thermal maximum; organicgeochemical and micropaleontologic evidence from the southern Tethyan margin (Egypt-Israel); Catastrophic events and mass extinctions; impacts and beyond, Spec. Pap. - Geol. Soc. Am., 356, 533-549, https://doi.org/10.1130/0-8137-2356-6.533, 2002.

Stassen, P., Thomas, E., and Speijer, R. P.: Integrated stratigraphy of the Paleocene-Eocene thermal maximum in the New Jersey Coastal Plain: Toward understanding the effects of global warming in a shelf environment, Paleoceanography, 27, 1-17, https://doi.org/10.1029/2012PA002323, 2012.

Stockmarr, J.: Tablets with spores used in absolute pollen analysis, Pollen et spores, 1971.

Stramma, L., Johnson, G. C., Sprintall, J., and Mohrholz, V.: Expanding oxygen-minimum zones in the tropical oceans, Science, 320, 655-658, https://doi.org/10.1126/science.1153847, 2008.

Tripati, A. K.: Tropical sea-surface temperature reconstruction for the early Paleogene using $\mathrm{Mg} / \mathrm{Ca}$ ratios of planktonic foraminifera, Paleoceanography, 18, 1101, https://doi.org/10.1029/2003PA000937, 2003.

Trommer, G., Siccha, M., van der Meer, M. T. J., Schouten, S., Sinninghe Damsté, J. S., Schulz, H., Hemleben, C., and Kucera, M.: Distribution of Crenarchaeota tetraether membrane lipids in surface sediments from the Red Sea, Org. Geochem., 40, 724-731, https://doi.org/10.1016/j.orggeochem.2009.03.001, 2009. van Hinsbergen, D. J. J., de Groot, L. V, van Schaik, S. J., Spakman, W., Bijl, P. K., Sluijs, A., Langereis, C. G., and Brinkhuis, H.: A Paleolatitude Calculator for Paleoclimate Studies, PLoS One, 10, e0126946, https://doi.org/10.1371/journal.pone.0126946, 2015.

Verschuren, D., Sinninghe Damsté, J. S., Moernaut, J., Kristen, I., Blaauw, M., Fagot, M., and Haug, G. H.: Half-precessional dynamics of monsoon rainfall near the East African Equator, Nature, 462, 637-641, https://doi.org/10.1038/nature08520, 2009.

Wagner, T.: Late Cretaceous to early Quaternary organic sedimentation in the eastern Equatorial Atlantic, Palaeogeogr. Palaeocl., 179, 113-147, https://doi.org/10.1016/S0031-0182(01)00415-1, 2002.

Westerhold, T., Röhl, U., Frederichs, T., Agnini, C., Raffi, I., Zachos, J. C., and Wilkens, R. H.: Astronomical calibration of the Ypresian timescale: implications for seafloor spreading rates and the chaotic behavior of the solar system?, Clim. Past, 13, 11291152, https://doi.org/10.5194/cp-13-1129-2017, 2017.

Williams, G. L., Damassa, S. P., Fensome, R. A., and Guerstein, R.: Wetzeliella and its allies - the "hole" story: a taxonomic revision of the Paleogene dinoflagellate subfamily Wetzelielloideae, Palynology, 39, 289-344, https://doi.org/10.1080/01916122.2014.993888, 2015.

Wilson, K. E., Maslin, M. A., Leng, M. J., Kingston, J. D., Deino, A. L., Edgar, R. K., and Mackay, A. W.: East African lake evidence for Pliocene millennial-scale climate variability, Geology, 42, 955-958, 2014.

Wing, S. L., Harrington, G. J., Smith, F. A., Bloch, J. I., Boyer, D. M., and Freeman, K. H.: Transient floral change and rapid global warming at the Paleocene-Eocene boundary, Science, 31, 993996, https://doi.org/10.1126/science.1116913, 2005.

Woulds, C., Cowie, G. G. L., Levin, L. A., Andersson, J. H., Middelburg, J. J., Vandewiele, S., Lamont, P. A., Larkin, K. E., Gooday, A. J., and Schumacher, S.: Oxygen as a control on sea floor biological communities and their roles in sedimentary carbon cycling, Limnol. Oceanogr., 52, 1698-1709, https://doi.org/10.4319/lo.2007.52.4.1698, 2007.

Wu, H., Zhang, S., Feng, Q., Jiang, G., Li, H., and Yang, T.: Milankovitch and sub-Milankovitch cycles of the early Triassic Daye Formation, South China and their geochronological and paleoclimatic implications, Gondwana Res., 22, 748-759, 2012.

Wuchter, C., Schouten, S., Coolen, M. J. L., and Sinninghe Damsté, J. S.: Temperature-dependent variation in the distribution of tetraether membrane lipids of marine Crenarchaeota: Implications for TEX86 paleothermometry, Paleoceanography, 19, 1-10, https://doi.org/10.1029/2004PA001041, 2004.

Yamaguchi, T. and Norris, R. D.: No place to retreat: Heavy extinction and delayed recovery on a Pacific guyot during the Paleocene-Eocene Thermal Maximum, Geology, 43, 443-446, 2015.

Zachos, J. C., Wara, M. W., Bohaty, S. M., Delaney, M. L., Petrizzo, M. R., Brill, A., Bralower, T. J., and Premoli-Silva, I.: A Transient Rise in Tropical Sea Surface Temperature During the Paleocene-Eocene Thermal Maximum, Science, 302, 15511554, https://doi.org/10.1126/science.1090110, 2003.

Zachos, J. C., Rohl, U., Schellenberg, S. A., Sluijs, A., Hodell, D. A., Kelly, D. C., Thomas, E., Nicolo, M. J., Raffi, I., Lourens, L. J., McCarren, H. K., and Kroon, D.: Rapid Acidification of the Ocean During the Paleocene-Eocene Thermal Maximum, Sci- 
ence, 308, 1611-1615, https://doi.org/10.1126/science.1109004, 2005.

Zachos, J. C., Dickens, G. R., and Zeebe, R. E.: An early Cenozoic perspective on greenhouse warming and carbon-cycle dynamics, Nature, 451, 279-283, https://doi.org/10.1038/nature06588, 2008.

Zeebe, R. E.: What caused the long duration of the PaleoceneEocene Thermal Maximum?, Paleoceanography, 28, 440-452, 2013.

Zeebe, R. E., Zachos, J. C., and Dickens, G. R.: Carbon dioxide forcing alone insufficient to explain PalaeoceneEocene Thermal Maximum warming, Nat. Geosci., 2, 576-580, https://doi.org/10.1038/ngeo578, 2009.

Zeebe, R. E., Ridgwell, A., and Zachos, J. C.: Anthropogenic carbon release rate unprecedented during the past 66 million years, Nat. Geosci., 9, 325-329, https://doi.org/10.1038/ngeo2681, 2016.

Zhou, X., Thomas, E., Winguth, A. M. E., Ridgwell, A., Scher, H., Hoogakker, B. A. A., Rickaby, R. E. M., and Lu, Z.: Expanded oxygen minimum zones during the late Paleocene-early Eocene: Hints from multiproxy comparison and ocean modeling, Paleoceanography, 1-15, https://doi.org/10.1002/2016PA003020, 2016.
Zonneveld, K. A. F., Versteegh, G. J. M., and De Lange, G. J.: Preservation of organic-walled dinoflagellate cysts in different oxygen regimes: a 10,000 year natural experiment, Mar. Micropaleontol., 29, 393-405, 1997.

Zonneveld, K. A. F., Versteegh, G. J. M., and Kodrans-Nsiah, M.: Preservation and organic chemistry of Late Cenozoic organicwalled dinoflagellate cysts: a review, Mar. Micropaleontol., 68, 179-197, 2008.

Zonneveld, K. A. F., Marret, F., Versteegh, G. J. M., Bogus, K., Bonnet, S., Bouimetarhan, I., Crouch, E., de Vernal, A., Elshanawany, R., Edwards, L., Esper, O., Forke, S., Grøsfjeld, K., Henry, M., Holzwarth, U., Kielt, J.-F., Kim, S.Y., Ladouceur, S., Ledu, D., Chen, L., Limoges, A., Londeix, L., Lu, S.-H., Mahmoud, M. S., Marino, G., Matsouka, K., Matthiessen, J., Mildenhal, D. C., Mudie, P., Neil, H. L., Pospelova, V., Qi, Y., Radi, T., Richerol, T., Rochon, A., Sangiorgi, F., Solignac, S., Turon, J.-L., Verleye, T., Wang, Y., Wang, Z., and Young, M.: Atlas of modern dinoflagellate cyst distribution based on 2405 data points, Rev. Palaeobot. Palyno., 191, 1197, https://doi.org/10.1016/j.revpalbo.2012.08.003, 2013. 